\title{
3D printed composite materials for craniofacial implants: current concepts, challenges and future directions
}

\author{
Swati Jindal ${ }^{1}$ (D) $\cdot$ Faisal Manzoor $^{1} \cdot$ Niall Haslam $^{2} \cdot$ Elena Mancuso $^{1}$ \\ Received: 25 June 2020 / Accepted: 18 November 2020 / Published online: 3 December 2020 \\ (C) The Author(s) 2020
}

\begin{abstract}
Millions of craniofacial surgeries are performed annually worldwide for craniofacial bones' replacement and augmentation. This represents a significant economic burden as well as aesthetic expectations. Autografts and allografts are the first choice for treatment of craniofacial defects; however, their limited availability and difficulty to shape have led to investigation for alternative strategies. Biomaterial-based approaches have been used for implantation as they have ample supply but their processing through conventional technologies present several drawbacks; the major one relates to the poor versatility towards the production of patient-specific implants. Additive manufacturing has gained considerable attention during the last decade, as it allows the manufacturing of implants according to patient need. Biomaterial implants can be additively manufactured but have one or more limitations of stress shielding, radiopacity, high strength to weight ratio and limited bone integration. Over the last few decades, composites are investigated to surmount the limitations with traditional implants and also improve their bone integration. This review provides an overview of the most recent polymeric composite-based biomaterials that have been used in combination with 3D printing technology for the development of patient-specific craniofacial implants. Starting with the conventional treatments, biomaterials available for the craniofacial implants, the additive manufacturing rationale are discussed. Also, the main challenges still associated with 3D printing of polymer-based composites are critically reviewed and the future perspective presented.
\end{abstract}

Keywords Composite materials $\cdot$ Additive manufacturing $\cdot 3 \mathrm{D}$ printing $\cdot$ Craniofacial implants

\section{Introduction}

Every year, approximately 69 million individuals worldwide suffer from traumatic head injuries, which represent an enormous economic burden on medical services [1], and the foremost cause of death and disability [2]. In 2016, 74,000 cases for traumatic head injury were reported in England [3]; these include craniofacial fractures, which may arise when human head and/or face are subjected to impact loading caused by road traffic accidents, sport injuries and antisocial behaviour [4-8]. The fractures caused by trauma are asymmetrical in

Swati Jindal

s.jindal@ulster.ac.uk

Elena Mancuso

e.mancuso@ulster.ac.uk

1 Nanotechnology and Integrated Bio-Engineering Centre (NIBEC), Ulster University, Shore Road, Newtownabbey BT37 0QB, UK

2 Axial 3D, Alexander House, 17a Ormeau Ave, Belfast BT2 8HD, UK shape as compared to congenital defects which are symmetrical [9]. However, the repair in both cases is challenging. Replacement or augmentation of the physical bone is the primary aim of craniofacial surgeries, although qualitative impacts on function of the bone such as issues of swallowing, orbital function, vision, eating, speech and restoration of facial contour symmetry also need to be addressed $[2,9,10]$.

Craniofacial surgeries were performed by many ancient civilisations such as Incas, Asians, North Africans, British and Polynesian populations with evidences dating back 7000 $\mathrm{BC}$ [11]. However, the first craniofacial surgery in medical literature, based on the use of an implant, was reported by Fallopius and Petronius in the sixteenth century, when gold plates were used to repair cranium defects [12]. This practice did not continue further because the idea of using prosthetics was not well accepted at that time and surgeons preferred to use the patient's own bone tissue. In eighteenth and nineteenth centuries, autografts represented the common practice. In this case, the tissue was explanted from a healthy site and used to treat the injured site. This would not cause any immunogenic complication; however, the extraction of tissue itself was the 
cause of a second injured site. The limited availability of autograft along with the poor specificity in both shape and size are the main drawbacks of this approach. The use of autografts was discontinued and substituted by the introduction of allografts and xenografts, including tissues harvested from cadaveric skulls, bovine, rabbit and canine bones. However, with time also these strategies were precluded, mainly due to their high immune response they caused $[12,13]$.

During the last century, non-biological prostheses became common for bone tissue repair. In World War I, metals such as silver and gold were considered the best candidates for craniofacial surgery, while in World War II, titanium (Ti) was frequently used $[13,14]$. Although metals have been used successfully for many years since, metallic implants do not meet all biomechanical requirements. Particularly, stress shielding around the implant is a frequent issue. This may occur at the interface between metal and bone due to inadequate load transfer and result in the surrounding bone loss [15]. Moreover, metallic based implants may corrode and also cause cytotoxic reactions by releasing metallic ions into the host body. Furthermore, their interference with radiation deriving from imaging techniques affects post-operative followup by preventing the monitoring of the healing process [16-18] To overcome these limitations, bioceramics such as hydroxyapatite (HA) and tri-calcium phosphate (TCP) have been investigated for craniofacial bone repair thanks to their excellent bioactivity and their chemical properties similar to that of natural human bone [19]. However, the low mechanical strength and the brittle nature of bulk ceramics circumscribe their application in bone repair [20]. In order to overcome the limitations of bioceramics, researchers have combined them with other materials. Bioceramics have successfully been used as a coating for metallic implants and to reinforce polymeric matrices [21-23]. Considerable research is on-going to develop materials that have suitable biomechanical characteristics for implantation. Specifically, polyetherether ketone (PEEK), polyetherketone ketone (PEKK), polymethylmethacrylate (PMMA), polyethylene (PE) and their composites [22, 24-26]. In addition to being biocompatible and mechanically strong, they have the advantage over metallic implants of being radiolucent. Hence, the radiographic imaging assessment of their fusion with native bone (i.e. magnetic resonance imaging (MRI), computed tomography (CT) and X-ray scans) is facilitated as opposed to the interference caused by metallic implants [26-28].

Matching the host geometry is important to achieve aesthetic pleasing results and also complimenting the biological function [29]. Traditional manufacturing techniques such as injection moulding [30], casting [31] and extrusion [32] have been used for manufacturing craniofacial implants; however, they are time-consuming and not cost-effective for the production of patient-specific implants, and also the accuracy and precision of injection moulded samples is subjected to shrinkage control $[33,34]$. In the last decade, greater attention has been given to the use of additive manufacturing (AM), and the opportunity this type of technologies offers towards the production of personalised implants [35]. AM, also referred as 3D printing, is a manufacturing technique capable of producing complex 3D geometrical structures in a layer-by-layer fashion, starting from a digital CAD (computer-aided designing) model [36]. Materials ranging from metal, ceramics, polymers and their composites can be processed by additive manufacturing technologies [37]. Nowadays, the use of biocompatible polymers such as PEEK, PEKK and PMMA in combination with additive manufacturing is gaining great interest for the development of custom-made and patient specific craniofacial implants [38,39], although the processing of polymer-based composites through $3 \mathrm{D}$ printing has been only marginally investigated for this specific clinical application [40].

In this review, the evolution of craniofacial implants will be discussed along with an overview of the most recent polymeric composite-based biomaterials that have been used in combination with $3 \mathrm{D}$ printing technology for the development of patient-specific craniofacial implants. The main challenges associated with 3D printing of biocompatible polymer-based composites will be critically reviewed. Finally, a roadmap for the future development of such implants will be laid out.

\section{Anatomical and biomechanical considerations for craniofacial implant development}

Craniofacial bones each have a unique physiology and function. This function needs to be considered when manufacturing implants as the functionality of these bones is so integral to our being [38]. Misshapen implants can give rise to social stigmatisation, poor body image and low self-esteem. Improper fitting of the implant can induce chronic pain and other debilitating conditions and seriously impair the quality of life of the patient. It is therefore imperative that the implant fits perfectly the host tissue defect, thus has a patient-specific design and an adequate inner geometry (i.e. porosity and interconnectivity), and is made of biomaterials that reflect the composition of human tissues, both in terms of biological and mechanical properties [38, 41, 42]. Adult human skull is made up of 22 complex bones, categorised into cranial and facial bones. Human skull provides a cavity to support the brain alongside providing structural support to the facial bones [43]. All bones, steadily joined together, provide a packed structure with little movement, except for the temporomandibular joint. Human brain case, known as the cranium, is formed of eight bones: two parietal bones, two temporal bones, one ethmoid bone, one frontal bone, one occipital bone and one sphenoid bone. The other fourteen facial bones support the eyes and the entrances to the digestive and respiratory tracts $[43,44]$. 
At the macroscopic level, human bone is based on two different categories, which differ in composition, apparent density as well as porosity, and they are known as cortical (or compact) and cancellous (or trabecular) bone. These differences lead to variations in bones' mechanical properties depending on the different anatomical location [45]. In addition to this, mechanical properties of human bones have been found to be dependent on gender, age group as well-diseased states. For such reasons, they are generally ascribed in a range of values, rather than a unique number. In Table 1, we list the mechanical properties of human cortical bone. The bone is usually subjected to compressive and tension forces during normal loading in both transverse and longitudinal directions; hence, the strength of the bone is variable in these directions [46]. Tensile strength is a measure of its ability to withstand tensile/pulling forces/loads, whereas compressive strength gives a measure of the compressive loads without failure/ fracture of the bone. Young's modulus is a mechanical property that defines stiffness of bone, i.e. deformation in bone shape when load is applied in a uniaxial direction [47]. The varying properties allow user to understand the prerequisite of implant material for the replacement of cranial bone.

Cranial bones are no exception and exhibit different properties as revealed by the wider literature. For instance, frontal bone is thicker, is less porous and has higher percent volume than temporal bone, which in turn increases its fracture toughness [48]. Motherway et al. measured the bending strength of right parietal, left parietal and frontal bones of the cranium, and they found values equal to $82.98 \mathrm{MPa}, 78.15 \mathrm{MPa}$ and 102.60 MPa respectively [48], thus indicating the slight variations in mechanical properties between left vs right parietal bones and significant difference between the bending strength of parietal and frontal bone, which is a direct consequence of the differences in porosity and structure of these bones. They also demonstrated that testing speed, sampling position and intracranial variation, all have a significant effect on mechanical performance. Similarly, Evans et al. found tensile strength of right human parietal bone was $12 \%$ higher than left parietal bone. By testing the compressive strength of right and left parietal bones, these were found similar in longitudinal direction while in the transverse direction, the compressive strength for the left parietal bone was $16 \%$ higher than the right side [49], hence showing variation of properties based on location and the direction of force applied.
As previously mentioned, the shape of cranial bones is asymmetrical and complex; therefore, the anatomical location of the defect dictates specificity in implant design [55]. Moreover, in order to address this variation, craniofacial implants should be designed to follow the contour of the defect and also have fixation plates in order to be attached to the surrounding native skull bone. Implants can be uniaxial if spanning either right or left side of the body or biaxial if traversing across the body midline. Uniaxial implants are easy to design as the unaffected side can be used as a template for designing the graft while biaxial implants are difficult to design as mirroring is not possible $[39,56]$. Hence, in order to address the biomechanical requirements, the defect type is another aspect that should be considered during the development process.

Regarding cranium defects, they can range from a few $\mathrm{cm}^{2}$ to larger than $100 \mathrm{~cm}^{2}$. Poukens et al. have classified cranial defects into six categories based on the complexity of designing, size and whether orbital rim is involved [57]. Type I, II and III defects do not involve the orbital rim, which is instead involved for the type IV, V, and VI. The defects with area less than $5 \mathrm{~cm}^{2}$ are classified as type I defects, greater than $5 \mathrm{~cm}^{2}$ but less than $100 \mathrm{~cm}^{2}$ are type II defects, greater than $100 \mathrm{~cm}^{2}$ are type III defects. If the area is less than $5 \mathrm{~cm}^{2}$ with orbital involvement, these are classified as type IV, whereas defects with area larger than $100 \mathrm{~cm}^{2}$ are classified as type $V$ defects. Lastly, type VI defects have area greater than $100 \mathrm{~cm}^{2}$ with crossing midline of the skull. Based on the different types of cranial defects, materials with different mechanical performance need to be used for the development of craniofacial implants. For example, cranium implants have to protect the brain from external impact and stress forces; hence, they require tough material, whereas for orbital floor implants, which are not subjected to any external forces and support the eye ball only structurally, materials with limited toughness are suitable enough [57].

\section{Conventional treatments}

For centuries, surgeons have attempted to repair craniofacial defects with animal tissues. In 1668, Van Meekeren successfully documented the first procedure grafting a dog skull bone into a war wounded soldier's head without adverse
Table 1 Mechanical properties of human cortical bone

\begin{tabular}{llll}
\hline & Longitudinal direction & Transverse direction & References \\
\hline Tensile strength (MPa) & $133-170$ & $43-64$ & {$[50,51]$} \\
Compressive strength (MPa) & $70-280$ & $133-167$ & {$[52-54]$} \\
Young's modulus (GPa) & $11-21$ & $5-13$ & {$[50,53,54]$} \\
\hline
\end{tabular}


immunological response [58], and in 1901, Marchand et al. reported that also animal horns could be accepted as xenografts with no negative response [59]. Later on, bones from other animals such as rabbits, eagles, apes, calves and gooses were used as xenografts in humans; however, due to ethical issues these approaches were soon abandoned [60-62]. On the other hand, good success with autografts provided negligible justification for further xenograft applications [59].

Autografts have been used historically for craniofacial defect repair due to their positive immune response, osteogenic cells retention and enhanced healing activity [63-65]. The first autograft-based craniofacial repair was credited to $\mathrm{Mr}$. Walther in 1821 [65]. Following this, in 1889, Seydel reported the first successful reconstruction of human cranium by using tibia bone tissue pieces. Moreover, bones harvested from ribs, scapula, ilium, sternum and fascia were also tested for cranial repair [66]. Although autografts are still considered as the "gold standard" for craniofacial repair, they are not risk-free approaches [25, 67-71]. Piitulainen et al. [72] and Matsuno et al. [73] reported $\sim 25 \%$ infectious complications following cranioplasty with autografts. Another complication with autografts is native bone resorption after the surgery, which is also dependant on patients age $[71,74,75]$. Bowers et al. reported that $50 \%$ paediatric patients, who underwent autograft-based surgery, experienced bone resorption in comparison to only $7 \%$ of adults [74]. In addition to these complications, another important aspect that limited the use of autografts over the years related to the poor customizable properties, for which shape and size of the injured tissue were rarely matched. Beyond that, the excision of bone from the donor site engenders an additional injury site, hence leading to longer recovery and extended operating times $[39,76,77]$.

The limitations associated with autografts were addressed in 1915, when for the first time Morestin reported the use of cadaver cartilage for craniofacial repair [78]. Cartilage is readily obtainable and easy to shape and its resistance to infection is an additional advantage for cranial bone repair. Several successful cases of cartilage-based cranioplasty were reported by Monroe [79]. However, it was soon realised that cartilage was not mechanically strong and did not show mineralisation potential. Therefore, it was then realised that cartilage was not a suitable material for cranial bone repair [80]. In 1917, Dambrin and Sicard investigated the potential of cadaveric skull for cranial reconstruction [81]; the collected bone was treated with sodium carbonate, alcohol, xylol and ether and ultimately heat sterilised, before implantation, in order to minimise the immune response [81]. However, due to impediments of bone resorption and the high risk of infection, nevertheless, sterilisation measures used to be applied, craniofacial reconstruction with cadaveric skull had limited application $[82,83]$. Therefore, the need to find alternative grafts, for which different shapes and sizes could be available readily and which did not initiate adverse immune response upon grafting was measured of paramount importance. In light of the above-mentioned limitations and in an effort to overcome the life-threatening challenges in craniofacial surgery, the adoption of alternative strategies revealed highly necessary.

\section{Biomaterials for craniofacial implants}

The bone has low thermal conductivity to protect damage to underlying brain tissue from heat transfer from the atmosphere; therefore, the implant material should be analogous to bone. Magnetism of the implant can interfere with the security screening, just as radiolucency interferes with the post-operative imaging assessment $[66,84]$. In addition to addressing the limitations of natural grafts, an ideal biomaterial for craniofacial implants should be biocompatible, have low heat conduction and are non-magnetic, radiolucent, durable, easy to process and cost-effective. Several biomaterials have been investigated during the years for craniofacial reconstruction in order to overcome the challenges associated with the use of autografts and allografts; these include metals, ceramics and polymers as well as a combination of them [66]. In this section, the different types of biomaterials currently available, along with their benefits and limitations towards the manufacturing of craniofacial implants, are reviewed and discussed.

Metals such as aluminium, gold, silver, titanium and their alloys, are among the oldest biomaterials used to repair craniofacial defects. Although, many have been abandoned during the years, because of associated medical complications; for example, aluminium caused infections and induced epilepsy in patients who had cranioplasty with this material [85]. In comparison, gold has low complication rates; however, it is very expensive, whereas silver is considered unfavourable due to its poor mechanical properties and high oxidation affinity and thus corrosion behaviour [86]. Surgical titanium grade 5 (Ti-6Al-5V), usually referred as titanium, is the most biocompatible metal and is widely used in cranium fixation devices (such as screws, plates), solid plates and meshes [87]. Though clinical applications of titanium date back to 1966 [88], its widespread use was only found after 1983 when Branemark demonstrated the superior biocompatibility and mechanical properties of this metal [89]. Additionally, titanium and its alloys have high corrosion resistance, good machinability and better mechanical properties in comparison to other metals, thus making them the elected materials in human bone replacement surgery [90]. However, the higher elastic modulus of titanium alloys $(\sim 110 \mathrm{GPa})$ with respect to human cortical bone (10-30 GPa) often is the cause of stress shielding effects at the bone-implant interface. Stress shielding occurs when metal implants, such as bone plates and screws, are used to repair fractures or in joint replacement surgery; the higher stiffness of the implant results in bone loss as a consequence of decreased physiologic loading of the bone [15, 91-93]. The 
stress shielding effect can be minimised by lowering the elastic modulus and increasing the porosity of the implant [94, 95]. For instance, Oh et al. prepared porous titanium implants, with porosity values around $30 \%$, via powder metallurgy and Young's modulus of these decreased to $25 \mathrm{GPa}$, thus resulting in the human cortical bone range [95]. However, the release of aluminium and vanadium ions from grade $5 \mathrm{Ti}$ alloy in the blood stream limited its use for long-term implantation [96, 97]. Titanium itself is non-toxic both in its ionic and in its particle form, and $\mathrm{Ti}$ ions are subjected to renal excretion [98]. However, corrosion product of titanium, called rutile, accumulates in the lymph nodes, liver, spleen, bone marrow and brain, thus leading to systemic toxicity [99]. Few studies have also reported the infectious complications associated with titanium implants, which led to the surgical removal of the implant itself. Bhatt et al. had to remove 32 craniofacial mini-plates out of 308 implanted in 153 patients due to infectious complications within 4 years of implantation [100]. Murthy et al. had to replace 6 titanium plates out of 163 due to infections from 76 patients over a 10-year period [101]. In addition to infections, which for titanium implants account $7-10 \%$ of the overall complications $[102,103]$, radiopacity is another drawback associated with the use of metal implants. Particularly, this often leads to artefacts during CT and MRI scanning and hence makes it difficult for follow-up medical imaging. Another limitation with metallic biomaterials is their poor biomimetic behaviour, which prevent cell-material communications, and thus the final integration of the implant [104]. In order to overcome this issue, surface treatments as coating or functionalisation have been adopted [104-106]. For instance, Palmquist et al. found stronger bone anchorage for laser-modified titanium alloy implants than the machined implants $[105,106]$. Metal implants offer a biocompatible and mechanically strong alternative to biologically derived treatment for replacing bone (Table 2), but considering their complications and limitations, the possibility to explore alternative biomaterials has been also examined.

Ceramics such as bioactive glasses (BAGs) and calcium phosphates have been then considered for craniofacial bone tissue repair [107]. The first BAG was synthetically manufactured in 1971 by Hench and afterward commercially known as Bioglass 45S5 [108, 109]. The main components of BAGs, $\mathrm{Na}_{2} \mathrm{O}, \mathrm{CaO}, \mathrm{SiO}_{2}$ and $\mathrm{P}_{2} \mathrm{O}_{5}$ support osteoblast cells. BAGs also bond with the host bone soft tissue without formation of fibrous tissue [110]. Their bioactivity, as assessed by Peltola et al. in a skull bone defect, revealed new bone formation evident from 4 weeks of implantation [111]. Although the elastic modulus of BAGs $(\sim 30 \mathrm{GPa})$ resembles the one of human bone, their amorphous structure makes them brittle and thus inappropriate for load-bearing applications [112]. Another shortcoming with BAGs is their limited processability; they cannot be reshaped during the surgery to improve the fit of the implant if required $[112,113]$. Another class of ceramics, calcium phosphates are highly biocompatible and have chemical compositions and structures that are very similar to the mineral phase of human bone [114]. Such materials can be resorbed through a cellmediated procedure involving osteoclast activity; for instance, the HA coating on implants is resorbed by the osteoclast activity during bone remodelling [115-117]. Tricalcium phosphates (TCP), e.g. beta-tricalcium phosphate ( $\beta$-TCP), are a type of calcium phosphate with $\mathrm{Ca} / \mathrm{P}$ very close to the natural bone tissue. Hence, they provide calcium and phosphorus in readily available form for development of new bone. Both HA and TCP are biocompatible and biodegradable, with HA degradation rate more suitable for orthopaedic applications allowing time for deposition of new bone [118]. Morphometric analysis by Eggli et al. revealed that up to $85 \%$ of TCP was degraded after 6 months of implantation in rabbits, whereas only $5.4 \%$ volume reduction observed with implanted HA in the same period, indicating a better match with the regeneration of new tissue [119]. Bioceramics are advantageous over metals as being more biocompatible and bioactive, although their mechanical properties are lower compared to the native bone, hence limiting their use as load-bearing implant materials and giving more promise as coating and/or reinforcing phase [120, 121]. In 2013, Brie et al. implanted HA craniofacial implants into 8 patients prepared via stereolithography and sintering. Since the implants were designed for individual patients the cosmetic results were satisfactory and no fractures or infections were observed to up to the 12month follow-up [19].

Due to an array of limitations observed with metallic and ceramic biomaterials, the use of polymers has been considered as alternative class for craniofacial repair, particularly due to their radiolucency, high strength to weight ratio, good processability and low cost in comparison to metals and ceramics [122]. Moreover, polymers avoid possible artefacts in imaging scanning like CT or MRI due to their radiolucency and being nonmagnetic, thus facilitating unobstructed post-operative clinical diagnoses. Among the others, PMMA, PEEK and PE are the polymers most widely used in craniofacial surgery. Porous $\mathrm{PE}$ is soft and frequently applied for the augmentation of facial bone [123, 124]. PMMA was the first synthetic material used for a biomedical application and is now broadly used as prosthetic fixation devices or orthopaedic devices due to its low toxicity and good handle ability during surgery $[125,126]$. However, despite the good qualities, PMMA implants show poor adhesion with the surrounding soft tissues [127]. Additionally, a large amount of heat is released during its polymerisation in vivo, causing the temperature rise up to $100^{\circ} \mathrm{C}$ which may cause damage to the surrounding soft tissues [128]. PEEK is a biocompatible and semi-crystalline thermoplastic polymer, possessing high heat and gamma ray tolerance, which allow for different sterilisation methods [56]. Strength, stiffness and radiolucency of PEEK are comparable to those of cortical bone [129]; however, due to its bioinert and hydrophobic nature, its binding ability with the surrounding tissues after 
Table 2 Summary of different biomaterials for implantation with their material properties

\begin{tabular}{|c|c|c|c|c|c|c|c|c|}
\hline Biomaterial & $\begin{array}{l}\text { Density } \\
\left(\mathrm{gr} / \mathrm{cm}^{3}\right)\end{array}$ & $\begin{array}{l}\text { Biological } \\
\text { response }\end{array}$ & Degradable & $\begin{array}{l}\text { Elastic modulus } \\
(\mathrm{GPa})\end{array}$ & $\begin{array}{l}\text { Ultimate tensile } \\
\text { strength }(\mathrm{MPa})\end{array}$ & $\begin{array}{l}\text { Yield strength } \\
\text { (MPa) }\end{array}$ & $\begin{array}{l}\text { Bending } \\
\text { strength (MPa) }\end{array}$ & References \\
\hline Co-Cr alloys & 9.1 & Biotolerant & No & 9.1 & 1147 & 629 & & {$[132,133]$} \\
\hline Stainless steel & 7.95 & Biotolerant & No & 193 & 670 & 366 & & {$[132,134]$} \\
\hline Titanium alloy & & Bioinert & No & 110 & $960-970$ & $850-900$ & & [135] \\
\hline Calcium phosphates & & Bioactive & Yes & $1.66-2.34$ & $6-10$ & & & {$[134,136,137]$} \\
\hline Bioactive glasses & 2.7 & Bioactive & Yes & 35 & & & 42 & {$[134,138]$} \\
\hline PEEK & 1.3 & Biotolerant & No & 4 & 93 & & 170 & {$[133,139,140]$} \\
\hline PMMA & 1.12 & Biotolerant & No & $1.5-4.1$ & $24-49$ & & 134 & [133] \\
\hline PLA & & Biotolerant & Yes & 1.6 & 70 & & & {$[141]$} \\
\hline PCL & 1.15 & Biotolerant & Yes & 0.3 & 17 & & & {$[141,142]$} \\
\hline
\end{tabular}

Biotolerant, the products released due to corrosion and wear of implant material may lead to toxic or allergic reactions and show fibrous connective tissue attachment; bioinert, the products released due to corrosion and wear of implant are non-toxic and show fibrous connective tissue attachment; bioactive, the products released and the surface of implant encourage cell attachment, differentiation and proliferation; develop a chemical bond of a cohesive nature with bone

implantation is very low $[130,131]$. Bioinertness is the common shortcoming that can be extended to the whole class of synthetic polymers and which encouraged researchers to move their focus into a new direction. The physico-chemical and mechanical properties of various biomaterials, for each of the three classes described above, have been summarised in Table 2. This provides a reference for their selection towards the development of an implant according to the requirements of the host tissue that needs to be replaced or repaired.

\section{Polymeric matrix composite materials}

Composite materials are the result of the combination of two or more phases, where the reinforcement element and the matrix are integrated to improve the properties of the final material [143]. Composite materials' properties depend upon the composition and the interaction between the individual phases [144]. Human bone is a clear example of natural composite material, based on mineral HA crystals embedded into an organic collagen phase [145]. In the context of craniofacial repair, recent literature has highlighted the use of composites to tailor the mechanical properties and enhance the bioactivity of the implant $[22,25,113,146]$.

Composites of PMMA have been investigated to address the issues of large amount of heat released during the polymerisation reaction of polymer and its limited osseointegration. For instance, composites of ceramics in PMMA have shown improved bioactivity, increased cell adhesion in vitro and reduction in the amount of heat released during the polymerisation as compared to PMMA alone. Moreover, PMMA composites with BAG, silicates, HA and TCP enhance the mechanical properties of PMMA in addition to its bioactivity [147-156]. HA and TCP incorporation significantly reduces the amount of heat generated during the polymerisation of PMMA and improve cell attachment [157-159]. For instance, Chu et al. and Fang et al. reported that the incorporation of HA, TCP and chitosan in PMMA significantly reduced the amount of heat released during polymerization [146, 160]. Furthermore, Fang et al. also observed improved in vitro and in vivo osseointegration of PMMA composites with TCP and chitosan [160].

PMMA/BAG composites have shown good bioactivity as well as enhanced mechanical strength [148, 161, 162]. For instance, composite of PMMA and silicate-based bioceramic showed good cell attachment, proper setting time and high mechanical strength as compared to PMMA alone [161]. Hamizah et al. prepared PMMA composites with HA and glass-ceramic that showed apatite layer formation in simulated body fluid (SBF), improved flexural strength and enhanced thermal properties [24]. Moreover, in vivo study by Haach et al. showed improved bioactivity of PMMA composites with HA and BAG; however, compressive strength decreased, although still within an acceptable range for this to be considered a bone substitute [25]. Ku et al. prepared PMMA composite with surface-modified HA, in order to enhance ceramic-polymer phase interaction. HA nanoparticles were modified with either ethylene glycol or $\varepsilon$-caprolactone before blending with PMMA; this enhanced the compressive strength of the composite along with improved bioactive surface [162]. Furthermore, PMMA/BAG custom-made craniofacial implants were clinically applied to repair calvarial and facial defects; 5-year follow-up found patients' clinical recovery with good aesthetic and functional outcome [113].

Composites of PEEK are becoming popular to enhance its bioactivity and to tailor the final mechanical properties, particularly for load-bearing orthopaedic applications [163]. Carbon-fibre reinforced PEEK (CFR-PEEK) material has 
been the first FDA-approved composite of PEEK used for biomedical applications. Elastic modulus and tensile strength of the composite increased with the increase of the percentage of carbon fibres [164-166]. Specifically, they increased from 3.79 GPa and 95.21 MPa to 7.37 GPa and 101.41 MPa respectively, by simply adding $5 \% \mathrm{w} / \mathrm{w} / \mathrm{CFR}$ into PEEK matrix [40]. In another study, the addition of $40 \mathrm{wt} \% \mathrm{HA}$ reduced the mechanical properties of PEEK due to the agglomeration and poor dispersion of ceramic particles in the polymeric matrix; for example, the ultimate tensile strength of PEEK decreased to $45 \mathrm{MPa}$ (i.e. reduction of $45 \%$ from $85 \mathrm{MPa}$, although were still within the range of mechanical strength of human cortical bone [167]). Kim et al. incorporated HA-coated calcium silicate spheres into PEEK to increase its bioactivity and mimic natural bone. They observed increased bioactivity with in vitro apatite formation as well as mechanical properties analogous to native bone [168]. Biomechanical properties of PEEK reinforced with strontium substituted hydroxyapatite (Sr-HA/PEEK) have been also investigated. The results evidenced an increased in vitro mineralisation and bending modulus by using 25-30\% w/w of Sr-HA in PEEK [169]. Nanosilica $\left(\mathrm{nSiO}_{2}\right)$ and nano-alumina $\left(\mathrm{nAl}_{2} \mathrm{O}_{3}\right)$ have been incorporated into PEEK in amount ranging between the 20 and 50\% $\mathrm{w} / \mathrm{w}$. The result was an improved mechanical performance both in terms of elastic modulus and tensile strength [170]. $\mathrm{Wu}$ et al. prepared composite of PEEK with nano-titania (n$\mathrm{TiO}_{2}$ ) and observed better biological properties of the composite with respect to the bare materials, i.e. enhanced cell attachment and increased osteoblast cell spreading [171]. The use of bioactive reinforced polymers is still widely investigated. In a very recent study, Ma et al. found that the addition of nano-hydroxyapatite improved the apatite formation ability of PEEK composites as well as increased the elastic modulus and bending strength in comparison to PEEK alone [172]. However, the manufacturing process Ma et al. adopted for the processing of the composite materials is still far from being patient specific.

\section{Rationale for the use of additive manufacturing for craniofacial implants}

Conventional technologies such as injection moulding, extrusion, forging and compaction have played a key role in manufacturing biomedical implants. Conventional methods of manufacturing can produce standardised parts cheaply and quickly in large quantities, although they cannot produce custom-made parts. AM instead allows the manufacture of complex 3D parts that can also be modified according to patient individual needs. Conventional technologies also struggle to produce parts which are complex and have a high degree of dimensional accuracy, with the need for a dedicated tool meaning that the cost of producing a part for a specific patient is prohibitive [173].

Since its introduction, AM technology makes it possible to produce customisable 3D objects with intricate shapes and great accuracy. Within the biomedical field, AM has allowed the manufacture of patient-specific implants (PSIs) bypassing the requirements of additional tooling and manufacturing cost [174, 175]. In essence, complex shapes are designed by CAD software or derived from CT data, custom-designed and produced with high precision and specific to the needs of the patient, as shown in Fig. 1. One example of this technique in practice is for bone implants. The bone is scanned by CT or MRI and used to generate a 2D Digital Imaging Communication and Medicine (DICOM) of the defected part. This is then converted using 3D design tools (e.g. CAD) into a 3D native format (e.g. Standard Tessellation Language (STL) for further processing [176-178]. STL is a widely accepted software standard and is compatible with CAD software for the manipulation and design of parts for $3 \mathrm{D}$ printers. A basic example of this working in practice is a bone being scanned using CT. The information is exported into the DICOM format and the soft tissue data filtered leaving only the bone data. This can then be used to design an implant which corrects the defect. This design is then converted to a $3 \mathrm{D}$ processing software package that is used to 3D print the exact structure required for that patient [176].

AM spans a variety of techniques, including extrusionbased printing, laser sintering and photo-polymerisation. In extrusion-based printing, the polymer in the form of filament is fed into the printing head which melts the polymer and extrudes it and the molten polymer is deposited layer after layer horizontally; an example is fused deposition modelling (FDM). In laser sintering, the feedstock is a powder which is deposited in a thin layer. A laser beam melts the powder particles, and another thin layer of powder is deposited on top and the process is repeated, layer upon layer, in order to build 3D structure. Examples of laser sintering include selective laser sintering (SLS), selective laser melting (SLM) and electron beam melting (EBM). Another form of AM is photo-polymerisation, in which the photo-sensitive liquid resin is cured and hardened by using light to produce a three-dimensional structure. Examples of this technique are stereolithography (SLA) and digital light processing (DLP).

Another benefit of AM for manufacture of implants is its versatility that allows the user to control the deposition of material in a three-dimensional space, which enables manufacture of complex shapes with pre-defined porosity. Implants can be designed with well-defined pores or channels. For example, mesh-like structures are produced for cranioplasty of skull defects which have predesigned holes or hinges for screwing to the skull [179]. The ongoing research in processing new biomaterials via 3D printing technologies and for craniofacial implants is described in the latter sections. 
Fig. 1 Design and manufacturing procedure for an implant: direct and indirect routes

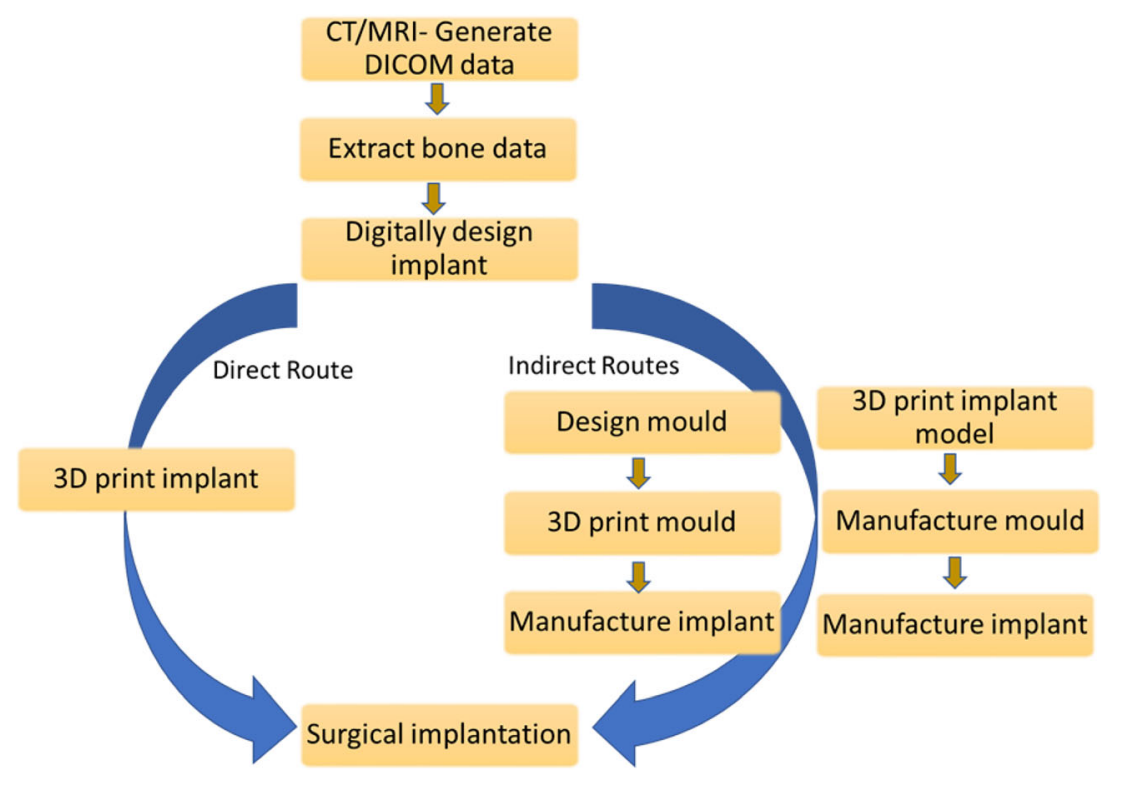

\section{3D printed composite materials for craniofacial implants}

In comparison to the production of monophasic parts, AM of composites requires optimisation of printing parameters in order to obtain the required porosity and mechanical strength. In relation to FDM, creating a composite-based filament is complicated, as not only must the diameter of the filament be consistent but also the raw components need to be well dispersed in order to avoid agglomeration that can affect the final print. This is further complicated by the differences in physico-chemical properties between polymer and ceramic phase $[142,180,181]$. For SLS, a fine powder is required with all the powder particles being in a specific size range in order to achieve evenly sized layers. Generally, the finer the powder, the better the surface finish. Prior to SLS printing, preprocessing of materials is necessary for optimal outcome. Researchers have also used techniques such as spray drying and freeze drying (for low-temperature polymers) to remove moisture. Due to the large surface area, atmospheric moisture can be absorbed onto the powder and this can impact the printing quality and the mechanical properties of the final printed parts $[182,183]$. Following an extensive review of the current literature, only a few research studies have been found, predominantly based on the use of FDM and SLS as elected procedures for printing composites, and whose findings are summarised in Table 3 . The mechanical properties of same formulation composites vary with the fabrication method used as seen in composites of CFR/PEEK [184, 185].

Hao et al. have optimised SLS printing parameters of HA reinforced PE composites, which also showed improved bioactivity of composite implants in vitro as HA particle are exposed on surface of the printed scaffold [186]. Subsequent tests for the biological behaviour include techniques to assess growth of cells and their differentiation, metabolism and the deposition of new bone [183, 186, 187]. Xia et al. assessed the new bone growth via CT scan at 3, 6 and 9 weeks after implantation of 3D printed bioactive scaffolds, based on the combination of PCL and HA, into rabbit femur (Fig. 2). The histology shows higher amount of new bone in defects implanted with PCL composite with 15\% HA in comparison to PCL alone, thus demonstrating the actual benefits of low amount of ceramic phase in bone regeneration [183]. Composites of HA with PLGA (poly(lactic-co-glycolic acid)) prepared by Huang et al. showed higher new bone deposition than autologous grafts [188]. Similar bioactivity assessments provided by other research groups show benefits of HA addition to composites for advancement of bioactivity by enhanced cell attachment, metabolism and mineral deposition as compared to pure polymers [21, 189]. The sintered materials have a porous structure with interconnected pores which is useful for ingrowth of bone and soft tissue. HA combined with PVA (polyvinyl acetate) can be processed via SLS to print scaffolds with enhanced bioactivity in comparison to PVA alone [182]. The possibility of 3D printing composites with tailorable bioactivity and mechanical properties proves their suitability as a manufacturing technique for craniofacial implants.

The $3 \mathrm{D}$ printing of composites is a promising step towards creation of craniofacial composite-based implants. However, their in vivo behaviour should be assessed prior to the clinical trials. The latest research into composites has successfully shown the promising in vivo behaviour of composites although not manufactured using AM but with conventional techniques, as listed in Table 4. For instance, $\mathrm{Yu}$ et al. and Ma et al. tested the moulded composites of PEEK and HA 


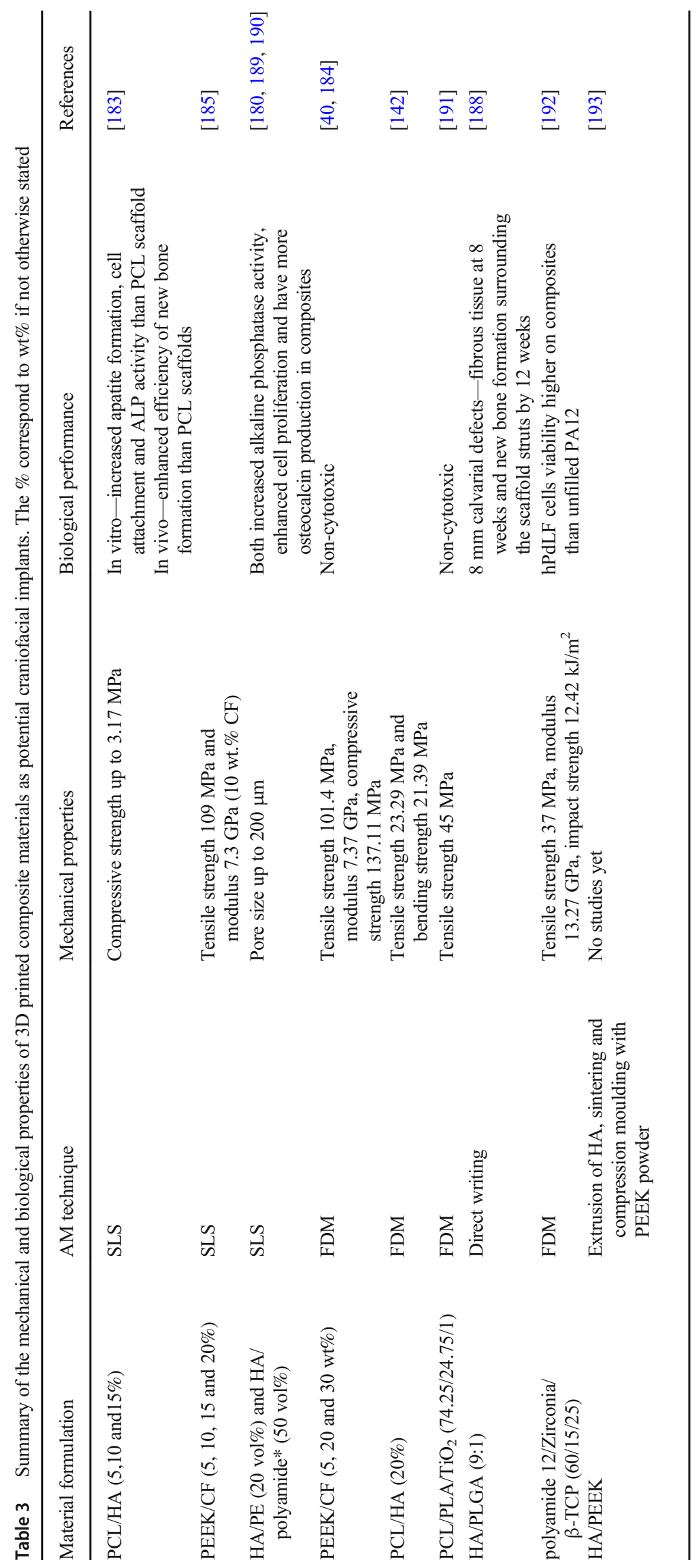



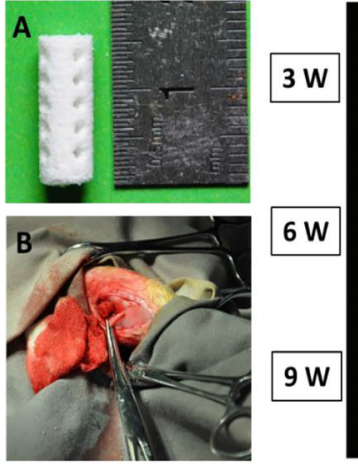

Fig. 2 Composite scaffold produced by SLS. (a) Sintered PCL/nano-HA $3 \mathrm{D}$ porous structure. (b) Implantation of the scaffold into the defect. (c) Micro-CT reconstructions after 3, 6 and 9 weeks of a cavitary defect production. Histological evaluation of new bone formation promoted by

with 10,20, 30 and $40 \%$ ceramic content in vitro. The apatite formation ability of composites was higher than PEEK alone after immersion in simulated body fluid [167]. Additionally, they evaluated the cell attachment, proliferation, spreading in vitro and osseointegration in a rabbit cranial defect model, all of which showed improvement with additional ceramic content [167]. In an attempt to improve the bioactivity of PEEK, Lee et al. cold sprayed HA onto PEEK and observed early cell adhesion and increase in viability of hBMSCs [194]. Another group added metal-doped HA to improve bioactivity of compression moulded PEEK; strontium containing composites outperformed HA/PEEK composites for in vitro mineralisation [169]. An alternative to isotropic composites, functionally graded composites were prepared in a 2-step process which advance the cell adhesion. Initially, composites were prepared by addition of HA during PEEK synthesis which gives excellent dispersion of HA in PEEK matrix. Three layers of different HA vol\% were stacked in a steel die before hot pressing to create functionally graded PEEK/ HA composites [195]. It can be concluded that even with different ways of manufacturing of composite scaffolds, the in vitro and in vivo results show increment in bioactivity with HA inclusion. Further research should be directed towards additively manufacturing of these composites as this should impart the physiological benefits of materials for implantation and will be vital in developing better fitting PSIs ensuring enhancement from off the shelf implants.

\section{Commercial craniofacial implants}

The use of AM in medicine is increasing at a rapid rate and the worldwide market of $3 \mathrm{D}$ printing healthcare market size is expected to reach $\$ 3.7$ billion by 2026 [202]. Commercial providers have resorted to different types of AM technologies in order to provide custom craniofacial implants from patient medical imaging data. A list of commercially available

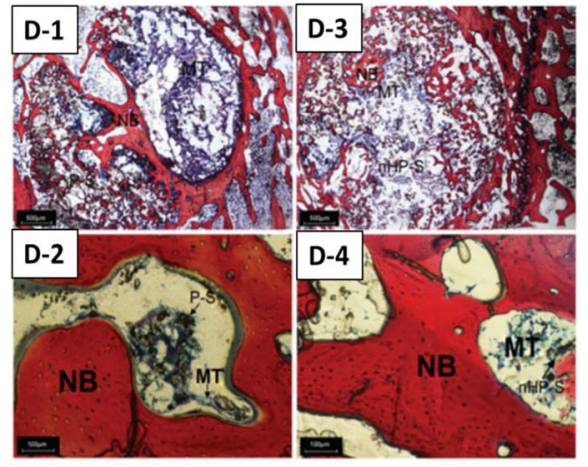

(D-1 and D-2) pure PCL and (D-3 and D-4) 15\% nano-HA/PCL 3D printed scaffolds at 9 weeks of implantation at $20 \times(\mathrm{D}-1$ and D-3) and $100 \times(\mathrm{D}-2$ and D-3) magnification. Reprinted with permission from [183]

craniofacial implants and the related provider is reported in Table 5. Currently available FDA-approved craniofacial implants are made from titanium, PEEK or PMMA and most centres use either off the shelf implants for craniofacial implantation or the custom-made implants from commercial companies. For instance, Stryker uses SLS for production of custom PEEK implants while OXPEKK used SLS for PEKK (polyetherketone ketone). The implants manufactured via AM are designed with prepatterned holes and also lattices which allows for space for soft tissue ingrowth and anchorage and also reduces the weight of the implant. Custom implants have improved fit and reduced operative times in comparison to the off the shelf implants which had to be adjusted in the operating theatre.

Although, the post-operative results of fit with these custom implants are very promising but there is limited integration with the native bone. Implant-bone integration is vital since transfer of load from implant to the bone keeps it healthy, or else there is progressive weakening of the adjacent bone which may cause implant exposure, infection and ultimately removal [203, 204]. To overcome this barrier, researchers are focussing on use of composites for improving implant-bone integration by increasing the bioactivity of implant materials.

The first step towards a composite craniofacial implant was taken by Swedish company OSSDSIGN, who have developed a composite of Ti mesh overlaid with calcium phosphate composition. The company claims the stability and fixation of implant is provided by the Ti mesh while the ceramic part helps in healing since calcium phosphates can be remodelled by osteoclasts. A retrospective clinical study has shown a reduced infection rate $(2 \%)$ in a 25 -month follow-up and tissue samples demonstrate in situ bone regeneration and osseointegration [196]. Another supplier of FDA-approved PEEK, Invibio Biomaterial Solutions supply PEEKOPTIMA ${ }^{\circledR}$ for craniofacial implants which are processed via $\mathrm{CAD} / \mathrm{CAM}$ for PSIs. They also provide PEEK- 


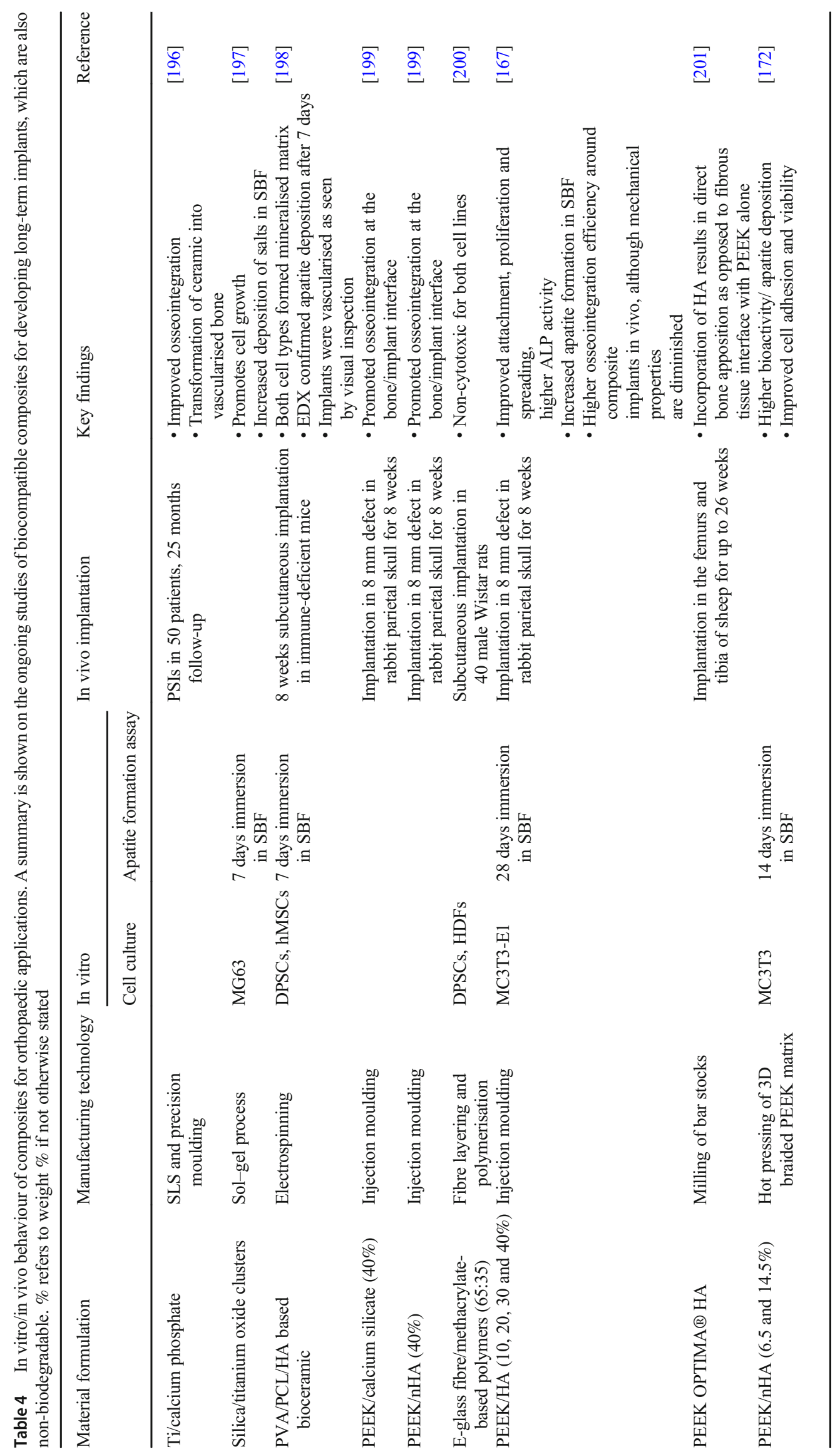


Table 5 Commercial implants used in craniofacial surgery including PSIs

\begin{tabular}{|c|c|c|}
\hline Establishment & Product details & Images \\
\hline BioArchitects & EBM Ti custom craniofacial implants & \\
\hline Ortho Baltic & $\begin{array}{l}\text { DMLS Ti custom craniofacial } \\
\text { implants }\end{array}$ & \\
\hline $\begin{array}{l}\text { Oxford Performance } \\
\text { Materials }\end{array}$ & $\begin{array}{l}\text { OsteoFab- OXPEKK } K^{\mathrm{TM}} \\
\text { SLS PEKK custom craniofacial } \\
\text { prostheses }\end{array}$ & \\
\hline DePuy Synthes & $\begin{array}{l}\text { TRUMATCH MatrixMANDIBLETM } \\
\text { Off the shelf fixation products }\end{array}$ & \\
\hline Stryker & $\begin{array}{l}\text { PEEK Customized cranial implant- } \\
\text { SLS PEEK }\end{array}$ & \\
\hline Stryker & $\begin{array}{l}\text { MEDPOR }{ }^{\circledR} \text { Customized cranial } \\
\text { implant - Porous PE }\end{array}$ & \\
\hline Stryker & PMMA Customized cranial implant & \\
\hline OssDsign $\mathrm{AB}$ & $\begin{array}{l}\text { OssDsign }^{\circledR} \text { - Cranial PSI- Ti and } \\
\text { bioceramic composite }\end{array}$ & \\
\hline
\end{tabular}

OPTIMA® HA, which is a composite with HA that shows improved bone-implant interface and reduction in fibrous tissue surrounding the implant [201].

\section{Conclusions and future perspective}

AM is highly versatile and increasingly being used for production of custom craniofacial implants of metals and polymers, although they are the two classes of biomaterials mainly used, as they provide appropriate structural replacement of the damaged/diseased craniofacial bone tissue, they still suffer from several limitations. Specifically, they are both classified as bioinert, and in the case of metallic implants, they often lead to stress shielding phenomena with the host tissue. In this work, the current state of the art towards the development of composite-based implants and also their processing via AM have been reviewed. The main focus was dedicated to polymeric based composites reinforced with a ceramic phase. According to the findings reported in the recent literature, through the use of composites, and by adjusting the component ratios of the main phases, it is possible to achieve an 
adequate balance in terms of physico-chemical, mechanical and biological properties.

Currently available in vivo studies, by using animal models have shown that the inclusion of HA in polymeric composites, especially PEEK, attains a material with adequate strength and most importantly with bioactive properties. Thus, PEEK/HA composites can be considered promising candidates for the development of craniofacial implants.

Regarding the opportunity to produce customised implants in the clinical setting, the major barriers towards the adoption of AM are no longer technological but rather relate to understanding the clinical effectiveness. Long-term follow-up studies on differences in success rates between different composite-based materials additively manufactured are needed toward their potential clinical application as implants. More work must be done to understand the tolerances and requirements of AM implants in a clinical setting as well as understanding the long-term implications of implanted AM parts in vivo. Also, materials' developers should direct efforts not only to achieve adequate biological and mechanical properties but also their easy processability via AM. From a technological development point of view, the prospects of manufacturing composites for PSIs is encouraging and further research should be addressed towards in vivo tests, clinical trials and regulatory approvals to incorporate into standard clinical practice. According to the United Nations, the population above 60 years is rising and would double by 2050 . This will in turn increase the demands for custom implants. In the future, the high demand of customised implants may require implant manufacturing unit in every orthopaedic hospital to produce implant on-site rather than outsourcing and AM would be the manufacturing technology of choice for implants serving the patient's needs and demands. As this demand for patientspecific implants increases, the need to democratise the design and manufacture of them will become more pressing. Point of care manufacturing is already becoming a reality in several leading hospitals worldwide. These highly integrated care facilities are demonstrating the impact of bringing together material scientists, clinicians, biomedical engineers and computer scientists to produce truly personalised care for patients. Personalised design of implants ensures the best outcomes for the patient over the lifetime of the implant. Lowering overall costs of such interventions allows the broader adoption of this approach, maximising the impact.

Acknowledgements The authors would like to acknowledge the North West Centre for Advanced Manufacturing (NW CAM) project, which is supported by the European Union's INTERREG VA Programme, managed by the Special EU Programmes Body (SEUPB). The views and opinions in this document do not necessarily reflect those of the European Commission or the Special EU Programmes Body (SEUPB). If you would like further information about NW CAM, please contact the lead partner, Catalyst, for details.
Open Access This article is licensed under a Creative Commons Attribution 4.0 International License, which permits use, sharing, adaptation, distribution and reproduction in any medium or format, as long as you give appropriate credit to the original author(s) and the source, provide a link to the Creative Commons licence, and indicate if changes were made. The images or other third party material in this article are included in the article's Creative Commons licence, unless indicated otherwise in a credit line to the material. If material is not included in the article's Creative Commons licence and your intended use is not permitted by statutory regulation or exceeds the permitted use, you will need to obtain permission directly from the copyright holder. To view a copy of this licence, visit http://creativecommons.org/licenses/by/4.0/.

\section{References}

1. Dewan MC, Rattani A, Gupta S, Baticulon RE, Hung YC, Punchak $M$ et al (2018) Estimating the global incidence of traumatic brain injury. J Neurosurg:1-18. https://doi.org/10.3171/ 2017.10.jns 17352

2. Maas AI, Menon DK, Adelson PD, Andelic N, Bell MJ, Belli A et al (2017) Traumatic brain injury: integrated approaches to improve prevention, clinical care, and research. Lancet Neurol 16(12):987-1048

3. Marincowitz C, Lecky F, Allgar V, Sheldon T (2019) Evaluation of the impact of the NICE head injury guidelines on inpatient mortality from traumatic brain injury: an interrupted time series analysis. BMJ Open 9(6):e028912

4. Sahoo D, Deck C, Yoganandan N, Willinger R (2016) Development of skull fracture criterion based on real-world head trauma simulations using finite element head model. J Mech Behav Biomed Mater 57:24-41. https://doi.org/10.1016/j. jmbbm.2015.11.014

5. Hardt N, Kessler P (2019) Craniofacial Fracture symptoms. In: Hardt N, Kessler P, Kuttenberger J (eds) Craniofacial trauma: diagnosis and management. Springer International Publishing, Cham, pp 91-130

6. Rajendra PB, Mathew TP, Agrawal A, Sabharawal G (2009) Characteristics of associated craniofacial trauma in patients with head injuries: an experience with 100 cases. J Emerg Trauma Shock 2(2):89-94. https://doi.org/10.4103/0974-2700.50742

7. Forrest CR, Hammer B, Manson PN, Markowitz B, Phillips JH, Prein J et al (1998) Craniofacial fractures. In: Prein J (ed) Manual of Internal fixation in the cranio-facial skeleton: techniques recommended by the AO/ASIF Maxillofacial Group. Springer Berlin Heidelberg, Berlin, pp 95-154

8. Enicker B, Madiba TE (2014) Cranial injuries secondary to assault with a machete. Injury. 45(9):1355-1358. https://doi.org/10.1016/ j.injury.2014.04.036

9. Bishara SE, Burkey PS, Kharouf JG (1994) Dental and facial asymmetries: a review. Angle Orthod 64(2):89-98. https://doi. org/10.1043/0003-3219(1994)064<0089:dafaar>2.0.co;2

10. Elsalanty ME, Genecov DG (2009) Bone grafts in craniofacial surgery. Craniomaxillofac Trauma Reconstr 2(03):125-134. https://doi.org/10.1055/s-0029-1215875

11. Velasco-Suarez M, Martinez JB, Oliveros RG, Weinstein PR (1992) Archaeological origins of cranial surgery: trephination in Mexico. Neurosurgery. 31(2):313-319

12. Aciduman A, Belen D (2007) The earliest document regarding the history of cranioplasty from the Ottoman era. Surg Neurol 68(3): 349-352. https://doi.org/10.1016/j.surneu.2006.10.073

13. Santoni-Rugiu P, Sykes PJ (2007) A history of plastic surgery. Springer-Verlag Berlin, Heidelberg 
14. Petersen RC (2014) Titanium implant osseointegration problems with alternate solutions using epoxy/carbon-fiber-reinforced composite. Metals. 4(4):549-569

15. Niinomi M, Nakai M (2011) Titanium-based biomaterials for preventing stress shielding between implant devices and bone. Int J Biomater. https://doi.org/10.1155/2011/836587

16. Sawyer-Glover AM, Shellock FG (2000) Pre-MRI procedure screening: recommendations and safety considerations for biomedical implants and devices. J Magn Reson Imaging 12(1):92106

17. Shellock FG (2001) Metallic neurosurgical implants: evaluation of magnetic field interactions, heating, and artifacts at 1.5-Tesla. J Magn Reson Imaging 14(3):295-299

18. Shellock FG (2002) Biomedical implants and devices: assessment of magnetic field interactions with a 3.0-Tesla MR system. J Magn Reson Imaging 16(6):721-732

19. Brie J, Chartier T, Chaput C, Delage C, Pradeau B, Caire F et al (2013) A new custom made bioceramic implant for the repair of large and complex craniofacial bone defects. J Cranio-Maxillofac Surg 41(5):403-407. https://doi.org/10.1016/j.jcms.2012.11.005

20. Uchida A, Nade S, McCARTNEY ER, Ching W (1984) The use of ceramics for bone replacement. A comparative study of three different porous ceramics. J Bone Joint Surg 66(2):269-275

21. Chua C, Leong K, Tan K, Wiria F, Cheah C (2004) Development of tissue scaffolds using selective laser sintering of polyvinyl alcohol/hydroxyapatite biocomposite for craniofacial and joint defects. J Mater Sci Mater Med 15(10):1113-1121

22. Aitasalo KM, Piitulainen JM, Rekola J, Vallittu PK (2014) Craniofacial bone reconstruction with bioactive fiber-reinforced composite implant. Head Neck 36(5):722-728

23. Kuroda K, Okido M (2012) Hydroxyapatite coating of titanium implants using hydroprocessing and evaluation of their osteoconductivity. Bioinorg Chem Appl 2012:730693. https:// doi.org/10.1155/2012/730693

24. Hamizah AS, Mariatti M, Othman R, Kawashita M, Noor Hayati AR (2012) Mechanical and thermal properties of polymethylmethacrylate bone cement composites incorporated with hydroxyapatite and glass-ceramic fillers. J Appl Polym Sci 125(S1):E661-E6E9. https://doi.org/10.1002/app.35295

25. Haach LCA, Purquerio BM, Silva Junior NF, Gaspar AMM, Fortulan CA (2014) Comparison of two composites developed to be used as bone replacement-PMMA/Bioglass $45 \mathrm{~S} 5 \AA$ microfiber and PMMA/hydroxyapatite. Bioceram Dev Appl 4(1):1000071 (1-3)

26. Johansson P, Jimbo R, Kozai Y, Sakurai T, Kjellin P, Currie F et al (2015) Nanosized hydroxyapatite coating on PEEK implants enhances early bone formation: a histological and three-dimensional investigation in rabbit bone. Materials. 8(7):3815-3830

27. Krüger T, Alter C, Reichel H, Birke A, Hein W, Spielmann R (1998) Possibilities of follow-up imaging after implantation of a carbon fiber-reinforced hip prosthesis. Aktuelle Radiol 8(2):81-86

28. Phan K, Hogan JA, Assem Y, Mobbs RJ (2016) PEEK-Halo effect in interbody fusion. J Clin Neurosci 24:138-140

29. Rotaru H, Schumacher R, Kim S-G, Dinu C (2015) Selective laser melted titanium implants: a new technique for the reconstruction of extensive zygomatic complex defects. Maxillofac Plast Reconstr Surg 37(1): 1

30. Chang SC, Tobias G, Roy AK, Vacanti CA, Bonassar LJ (2003) Tissue engineering of autologous cartilage for craniofacial reconstruction by injection molding. Plast Reconstr Surg 112(3):793799

31. Wolfaardt JF, Coss P (1996) An impression and cast construction technique for implant-retained auricular prostheses. J Prosthet Dent 75(1):45-49

32. Brown A, Banks P (1993) Late extrusion of alloplastic orbital floor implants. Br J Oral Maxillofac Surg 31(3):154-157
33. Ventola CL (2014) Medical applications for 3D printing: current and projected uses. Pharm Ther 39(10):704

34. Stansbury JW, Idacavage MJ (2016) 3D printing with polymers: challenges among expanding options and opportunities. Dent Mater 32(1):54-64

35. Campbell I, Bourell D, Gibson I (2012) Additive manufacturing: rapid prototyping comes of age. Rapid Prototyp J 18(4):255-258

36. Gibson I, Rosen DW, Stucker B (2014) Additive Manufacturing Technologies: 3D Printing, Rapid Prototyping, and Direct Digital Manufacturing. Springer, New York, NY. https://doi.org/10.1007/ 978-1-4939-2113-3

37. Bourell D, Kruth JP, Leu M, Levy G, Rosen D, Beese AM et al (2017) Materials for additive manufacturing. CIRP Ann 66(2): 659-681

38. Tevlin R, McArdle A, Atashroo D, Walmsley G, Senarath-Yapa $\mathrm{K}$, Zielins E et al (2014) Biomaterials for craniofacial bone engineering. J Dent Res 93(12):1187-1195. https://doi.org/10.1177/ 0022034514547271

39. Parthasarathy J (2014) 3D modeling, custom implants and its future perspectives in craniofacial surgery. Ann Maxillofac Surg $4(1): 9$

40. Han X, Yang D, Yang C, Spintzyk S, Scheideler L, Li P et al (2019) Carbon fiber reinforced PEEK composites based on 3Dprinting technology for orthopedic and dental applications. J Clin Med 8(2):240. https://doi.org/10.3390/jcm8020240

41. Visram SM, Gill D, Shute JT, Cunningham SJ (2019) Qualitative study to identify issues affecting quality of life in adults with craniofacial anomalies. Br J Oral Maxillofac Surg 57(1):47-52. https://doi.org/10.1016/j.bjoms.2018.06.011

42. Maji PK, Banerjee PS, Sinha A (2008) Application of rapid prototyping and rapid tooling for development of patientspecific craniofacial implant: an investigative study. Int J Adv Manuf Technol 36(5):510-515. https://doi.org/10.1007/s00170006-0868-9

43. Singh O, Varacallo M (2019) Anatomy, head and neck, frontal bone. StatPearls. StatPearls Publishing LLC, Treasure Island (FL)

44. Anderson BW, Al Kharazi KA (2019) Anatomy, head and neck, skull. StatPearls Publishing online book available on: https:// www.ncbi.nlm.nih.gov/books/NBK535424/

45. Rho J-Y, Kuhn-Spearing L, Zioupos P (1998) Mechanical properties and the hierarchical structure of bone. Med Eng Phys 20(2): 92-102. https://doi.org/10.1016/S1350-4533(98)00007-1

46. Li S, Demirci E, Silberschmidt VV (2013) Variability and anisotropy of mechanical behavior of cortical bone in tension and compression. J Mech Behav Biomed Mater 21:109-120

47. McElhaney JH, Fogle JL, Melvin JW, Haynes RR, Roberts VL, Alem NM (1970) Mechanical properties of cranial bone. J Biomech 3(5):495-511

48. Motherway JA, Verschueren P, Van der Perre G, Vander Sloten J, Gilchrist MD (2009) The mechanical properties of cranial bone: the effect of loading rate and cranial sampling position. J Biomech 42(13):2129-2135. https://doi.org/10.1016/j.jbiomech.2009.05.030

49. Evans FG, Lissner HR (1957) Tensile and compressive strength of human parietal bone. J Appl Physiol 10(3):493-497. https://doi. org/10.1152/jappl.1957.10.3.493

50. Havaldar R, Pilli SC, Putti BB (2014) Insights into the effects of tensile and compressive loadings on human femur bone. Adv Biomed Res 3:101. https://doi.org/10.4103/2277-9175.129375

51. Reilly DT, Burstein AH (1975) The elastic and ultimate properties of compact bone tissue. J Biomech 8(6):393-405. https://doi.org/ 10.1016/0021-9290(75)90075-5

52. Mow VC, Huiskes R (2005) Basic orthopaedic biomechanics \& mechano-biology. Lippincott Williams \& Wilkins, Philadelphia

53. Reilly DT, Burstein AH, Frankel VH (1974) The elastic modulus for bone. J Biomech 7(3):271-275. https://doi.org/10.1016/00219290(74)90018-9 
54. Evans FG, Wood JL (1976) Mechanical properties and density of bone in a case of severe endemic fluorosis. Acta Orthop Scand 47(5):489-495. https://doi.org/10.3109/17453677608988726

55. Wehmöller M, Weihe S, Rasche C, Scherer P, Eufinger H (eds) (2004) CAD/CAM-prefabricated titanium implants for large skull defects - clinical experience with 166 patients from 1994 to 2000. Int Congr Ser 1268:667-672

56. Hanasono MM, Goel N, DeMonte F (2009) Calvarial reconstruction with polyetheretherketone implants. Ann Plast Surg 62(6): 653-655

57. Poukens J, Laeven P, Beerens M, Nijenhuis G, Sloten JV, Stoelinga $P$ et al (2008) A classification of cranial implants based on the degree of difficulty in computer design and manufacture. Int J Med Rob Comput Assisted Surg 4(1):46-50. https://doi.org/ 10.1097/SAP.0b013e318184abc7

58. Hall BK (2014) Bones and cartilage: developmental and evolutionary skeletal biology. Elsevier Science

59. Durand JL, Renier D, Marchac D (1997) The history of cranioplasty. Ann Chir Plast Esthet 42(1):75-83

60. Galia CR, Moreira LF (2012) The biology of bone grafts, recent advances in arthroplasty. In: Dr. Samo Fokter (ed) InTech, pp 235-254. Available from: http://www.intechopen.com/books/ recent-advances-in-arthroplasty/the-biology-of-bone-grafts

61. Shah AM, Jung H, Skirboll S (2014) Materials used in cranioplasty: a history and analysis. Neurosurg Focus 36(4):E19

62. Durand J-L, Renier D, Marchac D (eds) (1997) The history of cranioplasty. Annales de chirurgie plastique et esthetique 42(1): 75-83

63. Artico M, Ferrante L, Pastore FS, Ramundo EO, Cantarelli D, Scopelliti D et al (2003) Bone autografting of the calvaria and craniofacial skeleton: historical background, surgical results in a series of 15 patients, and review of the literature. Surg Neurol 60(1):71-79

64. Raulo Y, Baruch J (1990) Use of the calvarium for bone grafting in cranio-maxillo-facial surgery. Chirurgie; memoires de l'Academie de chirurgie 116(4-5):359-362

65. Feroze AH, Walmsley GG, Choudhri O, Lorenz HP, Grant GA, Edwards MS (2015) Evolution of cranioplasty techniques in neurosurgery: historical review, pediatric considerations, and current trends. J Neurosurg 123(4):1098-1107. https://doi.org/10.3171/ 2014.11.jns 14622

66. Aydin S, Kucukyuruk B, Abuzayed B, Aydin S, Sanus GZ (2011) Cranioplasty: review of materials and techniques. J Neurosci Rural Pract 2(2):162-167

67. Kohn D, Sander-Beuermann A (1994) Donor-site morbidity after harvest of a bone-tendon-bone patellar tendon autograft. Knee Surg Sports Traumatol Arthrosc 2(4):219-223. https://doi.org/ 10.4103/0976-3147.83584

68. Chiarello E, Cadossi M, Tedesco G, Capra P, Calamelli C, Shehu A et al (2013) Autograft, allograft and bone substitutes in reconstructive orthopedic surgery. Aging Clin Exp Res 25(1):101-103

69. Lee C-H, Chung YS, Lee SH, Yang H-J, Son Y-J (2012) Analysis of the factors influencing bone graft infection after cranioplasty. J Trauma Acute Care Surg 73(1):255-260

70. Cheng Y-K, Weng H-H, Yang J-T, Lee M-H, Wang T-C, Chang C-N (2008) Factors affecting graft infection after cranioplasty. J Clin Neurosci 15(10):1115-1119

71. Rocque BG, Amancherla K, Lew SM, Lam S (2013) Outcomes of cranioplasty following decompressive craniectomy in the pediatric population: a systematic review. J Neurosurg Pediatr 12(2):120-125

72. Piitulainen JM, Kauko T, Aitasalo KMJ, Vuorinen V, Vallittu PK, Posti JP (2015) Outcomes of cranioplasty with synthetic materials and autologous bone grafts. World Neurosurg 83(5):708-714. https://doi.org/10.1016/j.wneu.2015.01.014

73. Matsuno A, Tanaka H, Iwamuro H, Takanashi S, Miyawaki S, Nakashima M et al (2006) Analyses of the factors influencing bone graft infection after delayed cranioplasty. Acta Neurochir 148(5):535-540

74. Bowers CA, Riva-Cambrin J, Hertzler DA, Walker ML (2013) Risk factors and rates of bone flap resorption in pediatric patients after decompressive craniectomy for traumatic brain injury. J Neurosurg Pediatr 11(5):526-532

75. Grant GA, Jolley M, Ellenbogen RG, Roberts TS, Gruss JR, Loeser JD (2004) Failure of autologous bone-assisted cranioplasty following decompressive craniectomy in children and adolescents. J Neurosurg Pediatr 100(2):163-168

76. Keating JF, Simpson AH, Robinson CM (2005) The management of fractures with bone loss. J Bone Joint Surg 87(2):142-150

77. Silber JS, Anderson DG, Daffner SD, Brislin BT, Leland JM, Hilibrand AS et al (2003) Donor site morbidity after anterior iliac crest bone harvest for single-level anterior cervical discectomy and fusion. Spine (Phila Pa 1976) 28(2):134-139. https://doi.org/ 10.1097/01.brs.0000041587.55176.67

78. Grant FC, Norcross NC (1939) Repair of cranial defects by cranioplasty. Ann Surg 110(4):488

79. Munroe A (1924) The operation of cartilage-cranioplasty. Can Med Assoc J 14(1):47

80. Roka YB (2017) Review of the history of materials used with experience with bone cement cranioplasty. Nepal J Neurosci 14(1):7-13

81. Edwards MS, Ousterhout DK (1987) Autogeneic skull bone grafts to reconstruct large or complex skull defects in children and adolescents. Neurosurgery. 20(2):273-280

82. Vanaclocha V, Bazan A, Saiz-Sapena N, Paloma V, Idoate M (1997) Use of frozen cranial vault bone allografts in the repair of extensive cranial bone defects. Acta Neurochir 139(7):653-660

83. Vanaclocha V, Sáiz-Sapena N, García-Casasola C, De Alava E (1997) Cranioplasty with autogenous autoclaved calvarial bone flap in the cases of tumoural invasion. Acta Neurochir 139(10): 970-976

84. Blake DP (1994) The use of synthetics in cranioplasty: a clinical review. Mil Med 159(6):466-469

85. Black SP (1978) Reconstruction of the supraorbital ridge using aluminum. Surg Neurol 9(2):121-128

86. Sones AD (1989) Complications with osseointegrated implants. J Prosthet Dent 62(5):581-585

87. Moghaddam NS, Elahinia M, Miller M, Dean D (eds) (2014) Enhancement of bone implants by substituting nitinol for titanium (Ti-6Al-4V): a modeling comparison. In Proceedings of the ASME 2014 Conference on Smart Materials, Adaptive Structures and Intelligent Systems, Newport, RI, USA, 8-10 September 2014

88. Hille GH (1966) Titanium for surgical implants. J Mater 1(2):373383

89. Branemark P-I (1983) Osseointegration and its experimental background. J Prosthet Dent 50:399-410

90. Niinomi M (2008) Mechanical biocompatibilities of titanium alloys for biomedical applications. J Mech Behav Biomed Mater 1(1):30-42

91. Huiskes R, Weinans H, Van Rietbergen B (1992) The relationship between stress shielding and bone resorption around total hip stems and the effects of flexible materials. Clin Orthop Relat Res 274:124-134

92. Noyama Y, Miura T, Ishimoto T, Itaya T, Niinomi M, Nakano T (2012) Bone loss and reduced bone quality of the human femur after total hip arthroplasty under stress-shielding effects by titanium-based implant. Mater Trans 53(3):565-570

93. Matassi F, Botti A, Sirleo L, Carulli C, Innocenti M (2013) Porous metal for orthopedics implants. Clin Cases Miner Bone Metab 10(2):111-115

94. Arabnejad S, Johnston B, Tanzer M, Pasini D (2017) Fully porous 3D printed titanium femoral stem to reduce stress-shielding following total hip arthroplasty. J Orthop Res 35(8):1774-1783 
95. Oh I-H, Nomura N, Masahashi N, Hanada S (2003) Mechanical properties of porous titanium compacts prepared by powder sintering. Scr Mater 49(12):1197-1202

96. Cao H, Liu X (2013) Activating titanium oxide coatings for orthopedic implants. Surf Coat Technol 233:57-64. https://doi.org/ 10.1016/j.surfcoat.2013.01.043

97. Jorgenson DS, Mayer MH, Ellenbogen RG, Centeno JA, Johnson FB, Mullick FG et al (1997) Detection of titanium in human tissues after craniofacial surgery. Plast Reconstr Surg 99(4):976-979 discussion 80-1

98. Jacobs JJ, Skipor AK, Black J, Urban R, Galante JO (1991) Release and excretion of metal in patients who have a total hipreplacement component made of titanium-base alloy. J Bone Joint Surg Am 73(10): 1475-1486

99. Case CP, Langkamer VG, James C, Palmer MR, Kemp AJ, Heap $\mathrm{PF}$ et al (1994) Widespread dissemination of metal debris from implants. J Bone Joint Surg 76(5):701-712

100. Bhatt V, Chhabra P, Dover MS (2005) Removal of miniplates in maxillofacial surgery: a follow-up study. J Oral Maxillofac Surg 63(6):756-760. https://doi.org/10.1016/j.joms.2005.02.005

101. Murthy AS, Lehman JA Jr (2005) Symptomatic plate removal in maxillofacial trauma: a review of 76 cases. Ann Plast Surg 55(6): 603-607. https://doi.org/10.1097/01.sap.0000183802.38116.37

102. Bakathir AA, Margasahayam MV, Al-Ismaily MI (2008) Removal of bone plates in patients with maxillofacial trauma: a retrospective study. Oral Surg Oral Med Oral Pathol Oral Radiol Endod 105(5): e32-e37. https://doi.org/10.1016/j.tripleo.2008.01.006

103. Rallis G, Mourouzis C, Papakosta V, Papanastasiou G, Zachariades N (2006) Reasons for miniplate removal following maxillofacial trauma: a 4-year study. J Craniomaxillofac Surg 34(7):435-439. https://doi.org/10.1016/j.jcms.2006.07.001

104. Nouri A, Hodgson PD, Wen C (2010) Biomimetic porous titanium scaffolds for orthopedic and dental applications. In: Biomimetics learning from nature, pp 415-450

105. Palmquist A, Lindberg F, Emanuelsson L, Brånemark R, Engqvist H, Thomsen P (2010) Biomechanical, histological, and ultrastructural analyses of laser micro- and nano-structured titanium alloy implants: a study in rabbit. J Biomed Mater Res A 92A(4):14761486. https://doi.org/10.1002/jbm.a.32439

106. Palmquist A, Omar OM, Esposito M, Lausmaa J, Thomsen P (2010) Titanium oral implants: surface characteristics, interface biology and clinical outcome. J R Soc Interface 7(suppl_5): S515-SS27

107. Van Gestel N, Geurts J, Hulsen D, Van Rietbergen B, Hofmann S, Arts J (2015) Clinical applications of S53P4 bioactive glass in bone healing and osteomyelitic treatment: a literature review. Biomed Res Int. https://doi.org/10.1155/2015/684826

108. De Aza P, De Aza A, Pena P, De Aza S (2007) Bioactive glasses and glass-ceramics. Boletin-Sociedad Espanola De Ceramica Y Vidrio 46(2):45-55

109. Hench LL, Splinter RJ, Allen W, Greenlee T (1971) Bonding mechanisms at the interface of ceramic prosthetic materials. J Biomed Mater Res 5(6):117-141

110. Vallet-Regí M, Ruiz-Hernández E (2011) Bioceramics: from bone regeneration to cancer nanomedicine. Adv Mater 23(44):51775218. https://doi.org/10.1002/adma.201101586

111. Peltola MJ, Aitasalo KMJ, Suonpää JTK, Yli-Urpo A, Laippala PJ, Forsback A-P (2003) Frontal sinus and skull bone defect obliteration with three synthetic bioactive materials. A comparative study. J Biomed Mater Res B Appl Biomater 66B(1):364-372. https://doi.org/10.1002/jbm.b.10023
112. Hench LL (ed) (1999) Bioactive glasses and glass-ceramics. Materials Science Forum. Trans Tech Publ 293:37-64. https:// doi.org/10.4028/www.scientific.net/MSF.293.37

113. Peltola MJ, Vallittu PK, Vuorinen V, Aho AAJ, Puntala A, Aitasalo KMJ (2012) Novel composite implant in craniofacial bone reconstruction. Eur Arch Otorhinolaryngol 269(2):623628. https://doi.org/10.1007/s00405-011-1607-x

114. Tanner K, Downes R, Bonfield W (1993) Clinical applications of hydroxyapatite reinforced materials. Br Ceram Trans 93(3):104-107

115. Annaz B, Hing K, Kayser M, Buckland T, Silvio LD (2004) Porosity variation in hydroxyapatite and osteoblast morphology: a scanning electron microscopy study. J Microsc 215(1):100-110

116. Tonino AJ, van der Wal BCH, Heyligers IC, Grimm B (2009) Bone remodeling and hydroxyapatite resorption in coated primary hip prostheses. Clin Orthop Relat Res 467(2):478-484. https://doi. org/10.1007/s1 1999-008-0559-y

117. Tonino AJ, Therin M, Doyle C (1999) Hydroxyapatite-coated femoral stems. Histology and histomorphometry around five components retrieved at post mortem. J Bone Joint Surg 81(1):148154. https://doi.org/10.1302/0301-620x.81b1.8948

118. Theiss F, Apelt D, Brand B, Kutter A, Zlinszky K, Bohner M et al (2005) Biocompatibility and resorption of a brushite calcium phosphate cement. Biomaterials. 26(21):4383-4394. https://doi. org/10.1016/j.biomaterials.2004.11.056

119. Eggli PS, Muller W, Schenk RK (1988) Porous hydroxyapatite and tricalcium phosphate cylinders with two different pore size ranges implanted in the cancellous bone of rabbits. A comparative histomorphometric and histologic study of bony ingrowth and implant substitution. Clin Orthop Relat Res 232:127-138

120. Stevens MM (2008) Biomaterials for bone tissue engineering. Mater Today 11(5):18-25. https://doi.org/10.1016/S13697021(08)70086-5

121. Kokubo T (2008) Bioceramics and their clinical applications. Woodhead Publishing, Cambridge

122. Rösler J, Harders H, Baeker M (2007) Mechanical behaviour of engineering materials: metals, ceramics, polymers, and composites. Springer-Verlag Berlin, Heidelberg

123. Odum BC, Bussard GM, Lewis RP, Lara WC, Edlich RF, Gampper TJ (1998) High-density porous polyethylene for facial bone augmentation. J Long-Term Eff Med Implants 8(1):3-17

124. Deshpande S, Munoli A (2010) Long-term results of high-density porous polyethylene implants in facial skeletal augmentation: an Indian perspective. Indian Journal of Plastic Surgery: official publication of the Association of Plastic Surgeons of India 43(1):34 39. https://doi.org/10.4103/0970-0358.63955

125. Murugan R, Ramakrishna S (2005) Development of nanocomposites for bone grafting. Compos Sci Technol 65(15):2385-2406. https://doi.org/10.1016/j.compscitech.2005.07.022

126. Grumezescu V, Grumezescu A (2019) Materials for biomedical engineering: thermoset and thermoplastic polymers. Elsevier

127. Freeman M, Bradley G, Revell P (1982) Observations upon the interface between bone and polymethylmethacrylate cement. J Bone Joint Surg 64(4):489-493

128. Lewis G (1997) Properties of acrylic bone cement: state of the art review. J Biomed Mater Res 38(2):155-182

129. Goldsmith D, Horowitz A, Orentlicher G (2012) Facial skeletal augmentation using custom facial implants. Atlas Oral Maxillofac Surg Clin North Am 20(1):119-134. https://doi.org/10.1016/j. cxom.2011.12.002

130. Williams DF, McNamara A, Turner RM (1987) Potential of polyetheretherketone (PEEK) and carbon-fibre-reinforced PEEK in medical applications. J Mater Sci Lett 6(2):188-190. https://doi. org/10.1007/bf01728981 
131. Arima Y, Iwata H (2007) Effect of wettability and surface functional groups on protein adsorption and cell adhesion using welldefined mixed self-assembled monolayers. Biomaterials. 28(20): 3074-3082. https://doi.org/10.1016/j.biomaterials.2007.03.013

132. AL-Mangour B, Mongrain R, Yue S (2013) Coronary stents fracture: an engineering approach (review). Mater Sci Appl 04(10): 16. https://doi.org/10.4236/msa.2013.410075

133. Saini M, Singh Y, Arora P, Arora V, Jain K (2015) Implant biomaterials: a comprehensive review. World J Clin Cases 3(1):5257. https://doi.org/10.12998/wjcc.v3.i1.52

134. Sykaras N, Iacopino AM, Marker VA, Triplett RG, Woody RD (2000) Implant materials, designs, and surface topographies: their effect on osseointegration. A literature review. Int J Oral Maxillofac Implants 15(5):675-690

135. Prakash C, Kansal HK, Pabla B, Puri S, Aggarwal A (2016) Electric discharge machining-a potential choice for surface modification of metallic implants for orthopedic applications: a review. Proc Inst Mech Eng B J Eng Manuf 230(2):331-353

136. Ambard AJ, Mueninghoff L (2006) Calcium phosphate cement: review of mechanical and biological properties. J Prosthodont 15(5):321-328. https://doi.org/10.1111/j.1532-849X.2006. 00129.x

137. Kikuchi M, Suetsugu Y, Tanaka J, Akao M (1997) Preparation and mechanical properties of calcium phosphate/copoly-L-lactide composites. J Mater Sci Mater Med 8(6):361-364. https://doi.org/ 10.1023/A:1018580816388

138. Thompson ID, Hench LL (1998) Mechanical properties of bioactive glasses, glass-ceramics and composites. Proc Inst Mech Eng H J Eng Med 212(2):127-136. https://doi.org/10.1243/ 0954411981533908

139. Panayotov IV, Orti V, Cuisinier F, Yachouh J (2016) Polyetheretherketone (PEEK) for medical applications. J Mater Sci Mater Med 27(7):118

140. Torstrick FB, Evans NT, Stevens HY, Gall K, Guldberg RE (2016) Do surface porosity and pore size influence mechanical properties and cellular response to PEEK? Clin Orthop Relat Res 474(11):2373-2383. https://doi.org/10.1007/s11999-0164833-0

141. Semba T, Kitagawa K, Ishiaku US, Hamada H (2006) The effect of crosslinking on the mechanical properties of polylactic acid/ polycaprolactone blends. J Appl Polym Sci 101(3):1816-1825. https://doi.org/10.1002/app.23589

142. Jiao Z, Luo B, Xiang S, Ma H, Yu Y, Yang W (2019) 3D printing of HA / PCL composite tissue engineering scaffolds. Adv Ind Eng Polym Res. https://doi.org/10.1016/j.aiepr.2019.09.003

143. Bouhfid N, Raji M, Boujmal R, Essabir H, Bensalah M-O, Bouhfid R et al (2019) 5 - Numerical modeling of hybrid composite materials. In: Jawaid M, Thariq M, Saba N (eds) Modelling of damage processes in biocomposites, fibre-reinforced composites and hybrid composites. Woodhead Publishing, pp 57-101

144. İsmal ÖE, Paul R (2018) 17 - composite textiles in highperformance apparel. In: McLoughlin J, Sabir T (eds) Highperformance apparel. Woodhead Publishing, pp 377-420

145. Piekarski K (1973) Analysis of bone as a composite material. Int J Eng Sci 11(6):557-565. https://doi.org/10.1016/0020-7225(73) 90018-9

146. Chu K, Oshida Y, Hancock E, Kowolik M, Barco T, Zunt S (2004) Hydroxyapatite/PMMA composites as bone cements. Biomed Mater Eng 14(1):87-105

147. Shinzato S, Nakamura T, Kokubo T, Kitamura Y (2001) A new bioactive bone cement: effect of glass bead filler content on mechanical and biological properties. Journal of Biomedical Materials Research: an official Journal of The Society for
Biomaterials, The Japanese Society for Biomaterials, and The Australian Society for Biomaterials and the Korean Society for Biomaterials 54(4):491-500

148. Samad HA, Jaafar M, Othman R, Kawashita M, Razak NHA (2011) New bioactive glass-ceramic: synthesis and application in PMMA bone cement composites. Biomed Mater Eng 21(4):247-258

149. Mousa WF, Kobayashi M, Shinzato S, Kamimura M, Neo M, Yoshihara $\mathrm{S}$ et al (2000) Biological and mechanical properties of PMMA-based bioactive bone cements. Biomaterials. 21(21): 2137-2146

150. Dalby M, Di Silvio L, Harper E, Bonfield W (2001) Initial interaction of osteoblasts with the surface of a hydroxyapatite-poly (methylmethacrylate) cement. Biomaterials. 22(13):1739-1747

151. Kwon S, Kim Y, Woo Y, Kim S, Park J (1997) Hydroxyapatite impregnated bone cement: in vitro and in vivo studies. Biomed Mater Eng 7(2):129-140

152. Kim SB, Kim YJ, Yoon TL, Park SA, Cho IH, Kim EJ et al (2004) The characteristics of a hydroxyapatite-chitosan-PMMA bone cement. Biomaterials. 25(26):5715-5723

153. Liu-Snyder P, Webster TJ (2008) Developing a new generation of bone cements with nanotechnology. Curr Nanosci 4(1):111-118

154. Serbetci K, Korkusuz F, Hasirci N (2004) Thermal and mechanical properties of hydroxyapatite impregnated acrylic bone cements. Polym Test 23(2):145-155

155. Khandaker M, Vaughan MB, Morris TL, White JJ, Meng Z (2014) Effect of additive particles on mechanical, thermal, and cell functioning properties of poly (methyl methacrylate) cement. Int J Nanomedicine 9:2699

156. Aghyarian S, Rodriguez LC, Chari J, Bentley E, Kosmopoulos V, Lieberman IH et al (2014) Characterization of a new composite PMMA-HA/Brushite bone cement for spinal augmentation. J Biomater Appl 29(5):688-698

157. Lin L-C, Chang S-J, Kuo SM, Chen SF, Kuo CH (2005) Evaluation of chitosan/ $\beta$-tricalcium phosphate microspheres as a constituent to PMMA cement. J Mater Sci Mater Med 16(6):567574. https://doi.org/10.1007/s10856-005-0533-0

158. Moursi AM, Winnard AV, Winnard PL, Lannutti JJ, Seghi RR (2002) Enhanced osteoblast response to a polymethylmethacrylate-hydroxyapatite composite. Biomaterials. 23(1):133-144

159. Yang JM, Shyu JS, Chen HL (1997) Polymerization of acrylic bone cement investigated by differential scanning calorimetry: effects of heating rate and TCP content. Polym Eng Sci 37(7): 1182-1187

160. Fang C-H, Lin Y-W, Sun J-S, Lin F-H (2019) The chitosan/tricalcium phosphate bio-composite bone cement promotes better osteo-integration: an in vitro and in vivo study. J Orthop Surg Res 14(1):162. https://doi.org/10.1186/s13018-019-1201-2

161. Chen L, Zhai D, Huan Z, Ma N, Zhu H, Wu C et al (2015) Silicate bioceramic/PMMA composite bone cement with distinctive physicochemical and bioactive properties. RSC Adv 5(47):3731437322. https://doi.org/10.1039/C5RA04646G

162. Ku K-L, Wu Y-S, Wang C-Y, Hong D-W, Chen Z-X, Huang C-A et al (2019) Incorporation of surface-modified hydroxyapatite into poly (methyl methacrylate) to improve biological activity and bone ingrowth. R Soc Open Sci 6(5):182060

163. Torstrick FB, Safranski DL, Burkus JK, Chappuis JL, Lee CSD, Guldberg RE et al (2017) Getting PEEK to stick to bone: the development of porous PEEK for interbody fusion devices. Tech Orthop (Rockville, Md) 32(3):158-166. https://doi.org/10.1097/ BTO.0000000000000242

164. Wang QQ, Wu JJ, Unsworth A, Briscoe A, Jarman-Smith M, Lowry C et al (2012) Biotribological study of large diameter 
ceramic-on-CFR-PEEK hip joint including fluid uptake, wear and frictional heating. J Mater Sci Mater Med 23(6):1533-1542

165. Brockett CL, Carbone S, Fisher J, Jennings LM (2017) PEEK and CFR-PEEK as alternative bearing materials to UHMWPE in a fixed bearing total knee replacement: an experimental wear study. Wear: an international journal on the science and technology of friction lubrication and wear 374-375:86-91. https://doi.org/10. 1016/j.wear.2016.12.010

166. Schwitalla AD, Spintig T, Kallage I, Müller W-D (2015) Flexural behavior of PEEK materials for dental application. Dent Mater 31(11):1377-1384

167. Ma R, Guo D (2019) Evaluating the bioactivity of a hydroxyapatite-incorporated polyetheretherketone biocomposite. J Orthop Surg Res 14(1):32. https://doi.org/10.1186/s13018-0191069-1

168. Kim IY, Sugino A, Kikuta K, Ohtsuki C, Cho SB (2009) Bioactive composites consisting of PEEK and calcium silicate powders. J Biomater Appl 24(2):105-118. https://doi.org/10. $1177 / 0885328208094557$

169. Wong K, Wong C, Liu W, Pan H, Fong M, Lam W et al (2009) Mechanical properties and in vitro response of strontiumcontaining hydroxyapatite/polyetheretherketone composites. Biomaterials. 30(23-24):3810-3817

170. Kuo M, Tsai C, Huang J, Chen M (2005) PEEK composites reinforced by nano-sized $\mathrm{SiO} 2$ and $\mathrm{A} 12 \mathrm{O} 3$ particulates. Mater Chem Phys 90(1):185-195

171. Wu X, Liu X, Wei J, Ma J, Deng F, Wei S (2012) Nano-TiO2/ PEEK bioactive composite as a bone substitute material: in vitro and in vivo studies. Int J Nanomedicine 7:1215

172. Ma J, Li ZJ, Xue YZB, Liang XY, Tan ZJ, Tang B (2020) Novel PEEK/nHA composites fabricated by hot-pressing of 3D braided PEEK matrix. Adv Compos Hybrid Mater. https://doi.org/10. 1007/s42114-020-00147-3

173. Ahn SH, Montero M, Odell D, Roundy S, Wright PK (2002) Anisotropic material properties of fused deposition modeling ABS. Rapid Prototyp J 8(4):248-257

174. Rachmiel A, Shilo D, Blanc O, Emodi O (2017) Reconstruction of complex mandibular defects using integrated dental custom-made titanium implants. Br J Oral Maxillofac Surg 55(4):425-427. https://doi.org/10.1016/j.bjoms.2017.01.006

175. Tofail SAM, Koumoulos EP, Bandyopadhyay A, Bose S, O'Donoghue L, Charitidis C (2018) Additive manufacturing: scientific and technological challenges, market uptake and opportunities. Mater Today 21(1):22-37. https://doi.org/10.1016/j. mattod.2017.07.001

176. J-h O (2018) Recent advances in the reconstruction of craniomaxillofacial defects using computer-aided design/computeraided manufacturing. Maxillofac Plast Reconstr Surg 40(1):2. https://doi.org/10.1186/s40902-018-0141-9

177. Owusu JA, Boahene K (2015) Update of patient-specific maxillofacial implant. Curr Opin Otolaryngol Head Neck Surg 23(4): 261-264. https://doi.org/10.1097/moo.0000000000000175

178. Zhao L, Patel PK, Cohen M (2012) Application of virtual surgical planning with computer assisted design and manufacturing technology to cranio-maxillofacial surgery. Arch Plast Surg 39(4): 309-316. https://doi.org/10.5999/aps.2012.39.4.309

179. Bonda DJ, Manjila S, Selman WR, Dean D (2015) The recent revolution in the design and manufacture of cranial implants: modern advancements and future directions. Neurosurgery. 77(5): 814-824. https://doi.org/10.1227/NEU.0000000000000899

180. Zhang Y, Hao L, Savalani MM, Harris RA, Tanner KE (2008) Characterization and dynamic mechanical analysis of selective laser sintered hydroxyapatite-filled polymeric composites. J
Biomed Mater Res A 86A(3):607-616. https://doi.org/10.1002/ jbm.a.31622

181. Tan KH, Chua CK, Leong KF, Cheah CM, Cheang P, Abu Bakar MS et al (2003) Scaffold development using selective laser sintering of polyetheretherketone-hydroxyapatite biocomposite blends. Biomaterials. 24(18):3115-3123. https://doi.org/10.1016/ S0142-9612(03)00131-5

182. Wiria FE, Chua CK, Leong KF, Quah ZY, Chandrasekaran M, Lee MW (2008) Improved biocomposite development of poly(vinyl alcohol) and hydroxyapatite for tissue engineering scaffold fabrication using selective laser sintering. J Mater Sci Mater Med 19(3):989-996. https://doi.org/10.1007/s10856-007-3176-5

183. Xia Y, Zhou P, Cheng X, Xie Y, Liang C, Li C et al (2013) Selective laser sintering fabrication of nano-hydroxyapatite/poly- $\varepsilon$ caprolactone scaffolds for bone tissue engineering applications. Int J Nanomedicine 8:4197-4213. https://doi.org/10.2147/IJN.S50685

184. Stepashkin AA, Chukov DI, Senatov FS, Salimon AI, Korsunsky AM, Kaloshkin SD (2018) 3D-printed PEEK-carbon fiber (CF) composites: structure and thermal properties. Compos Sci Technol 164:319-326. https://doi.org/10.1016/j.compscitech.2018.05.032

185. Yan M, Tian X, Peng G, Li D, Zhang X (2018) High temperature rheological behavior and sintering kinetics of $\mathrm{CF} / \mathrm{PEEK}$ composites during selective laser sintering. Compos Sci Technol 165: 140-147. https://doi.org/10.1016/j.compscitech.2018.06.023

186. Hao L, Savalani M, Zhang Y, Tanner K, Harris R (2006) Selective laser sintering of hydroxyapatite reinforced polyethylene composites for bioactive implants and tissue scaffold development. Proc Inst Mech Eng H J Eng Med 220(4):521-531

187. Pierantozzi D, Scalzone A, Jindal S, Stīpniece L, Šalma-Ancāne K, Dalgarno K, Gentile P, Mancuso E (2020) 3D printed Srcontaining composite scaffolds: Effect of structural design and material formulation towards new strategies for bone tissue engineering. Compos Sci Technol 191:108069

188. Huang Y-H, Jakus AE, Jordan SW, Dumanian Z, Parker K, Zhao L et al (2019) Three-dimensionally printed hyperelastic bone scaffolds accelerate bone regeneration in critical-size calvarial bone defects. Plast Reconstr Surg 143(5):1397-1407

189. Zhang Y, Hao L, Savalani M, Harris RA, Di Silvio L, Tanner K (2009) In vitro biocompatibility of hydroxyapatite-reinforced polymeric composites manufactured by selective laser sintering. Journal of Biomedical Materials Research Part A: an official journal of The Society for Biomaterials, The Japanese Society for Biomaterials, and The Australian Society for Biomaterials and the Korean Society for Biomaterials 91(4):1018-1027

190. Tanner K (2010) Bioactive ceramic-reinforced composites for bone augmentation. J R Soc Interface 7(suppl_5):S541-SS57

191. Nájera SE, Michel M, Kim N-S (2018) 3D Printed PLA/PCL/TiO 2 composite for bone replacement and grafting. MRS Adv 3(40): 2373-2378

192. Abdullah AM, Rahim TNAT, Hamad WNFW, Mohamad D, Akil HM, Rajion ZA (2018) Mechanical and cytotoxicity properties of hybrid ceramics filled polyamide 12 filament feedstock for craniofacial bone reconstruction via fused deposition modelling. Dent Mater 34(11):e309-ee16. https://doi.org/10.1016/j.dental.2018.09.006

193. Vaezi M, Yang S (2015) A novel bioactive PEEK/HA composite with controlled 3D interconnected HA network. Intl J Bioprint 1(1):66-76

194. Lee JH, Jang HL, Lee KM, Baek H-R, Jin K, Hong KS et al (2013) In vitro and in vivo evaluation of the bioactivity of hydroxyapatitecoated polyetheretherketone biocomposites created by cold spray technology. Acta Biomater 9(4):6177-6187. https://doi.org/10. 1016/j.actbio.2012.11.030 
195. Ma R, Fang L, Luo Z, Weng L, Song S, Zheng R et al (2014) Mechanical performance and in vivo bioactivity of functionally graded PEEK-HA biocomposite materials. J Sol-Gel Sci Technol 70(3):339-345. https://doi.org/10.1007/s10971-0143287-7

196. Kihlström Burenstam Linder L, Birgersson U, Lundgren K, Illies C, Engstrand T (2019) Patient-specific titanium-reinforced calcium phosphate implant for the repair and healing of complex cranial defects. World Neurosurg 122:e399-e407. https://doi.org/10. 1016/j.wneu.2018.10.061

197. Chen I-H, Lian M-J, Fang W, Huang B-R, Liu T-H, Chen J-A et al (2019) In vitro properties for bioceramics composed of silica and titanium oxide composites. Appl Sci 9(1):66

198. Prabha RD, Kraft DCE, Harkness L, Melsen B, Varma H, Nair PD et al (2018) Bioactive nano-fibrous scaffold for vascularized craniofacial bone regeneration. J Tissue Eng Regen Med 12(3): e1537-e1e48. https://doi.org/10.1002/term.2579

199. Ma R, Yu Z, Tang S, Pan Y, Wei J, Tang T (2016) Osseointegration of nanohydroxyapatite-or nano-calcium silicate-incorporated polyetheretherketone bioactive composites in vivo. Int J Nanomedicine 11:6023

200. Lazar M-A, Rotaru H, Bâldea I, Bosca AB, Berce CP, Prejmerean $\mathrm{C}$ et al (2016) Evaluation of the biocompatibility of new fiber- reinforced composite materials for craniofacial bone reconstruction. J Craniofac Surg 27(7):1694-1699

201. Walsh WR, Pelletier MH, Bertollo N, Christou C, Tan C (2016) Does PEEK/HA enhance bone formation compared with PEEK in a sheep cervical fusion model? Clin Orthop Relat Res 474(11): 2364-2372. https://doi.org/10.1007/s1 1999-016-4994-x

202. Tenzin K, Onkar S (2019) 3D Printing Healthcare Market by component. Allied Market Research. https://www. alliedmarketresearch.com/3d-printing-healthcare-market. Accessed 26 Nov 2020

203. Thien A, King NKK, Ang BT, Wang E, Ng I (2015) Comparison of polyetheretherketone and titanium cranioplasty after decompressive craniectomy. World Neurosurg 83(2):176-180. https:// doi.org/10.1016/j.wneu.2014.06.003

204. Punchak M, Chung LK, Lagman C, Bui TT, Lazareff J, Rezzadeh $\mathrm{K}$ et al (2017) Outcomes following polyetheretherketone (PEEK) cranioplasty: systematic review and meta-analysis. J Clin Neurosci 41:30-35. https://doi.org/10.1016/j.jocn.2017.03.028

Publisher's note Springer Nature remains neutral with regard to jurisdictional claims in published maps and institutional affiliations. 